\title{
A revanche do Leviatã: Estados rebeldes como desafio à ideia única
}

\author{
The Leviathan revenge: \\ rogue States as a challenge \\ to the pensée unique
}

\section{HugO R. Henriques* \\ joão pedro B. de carvalho**}

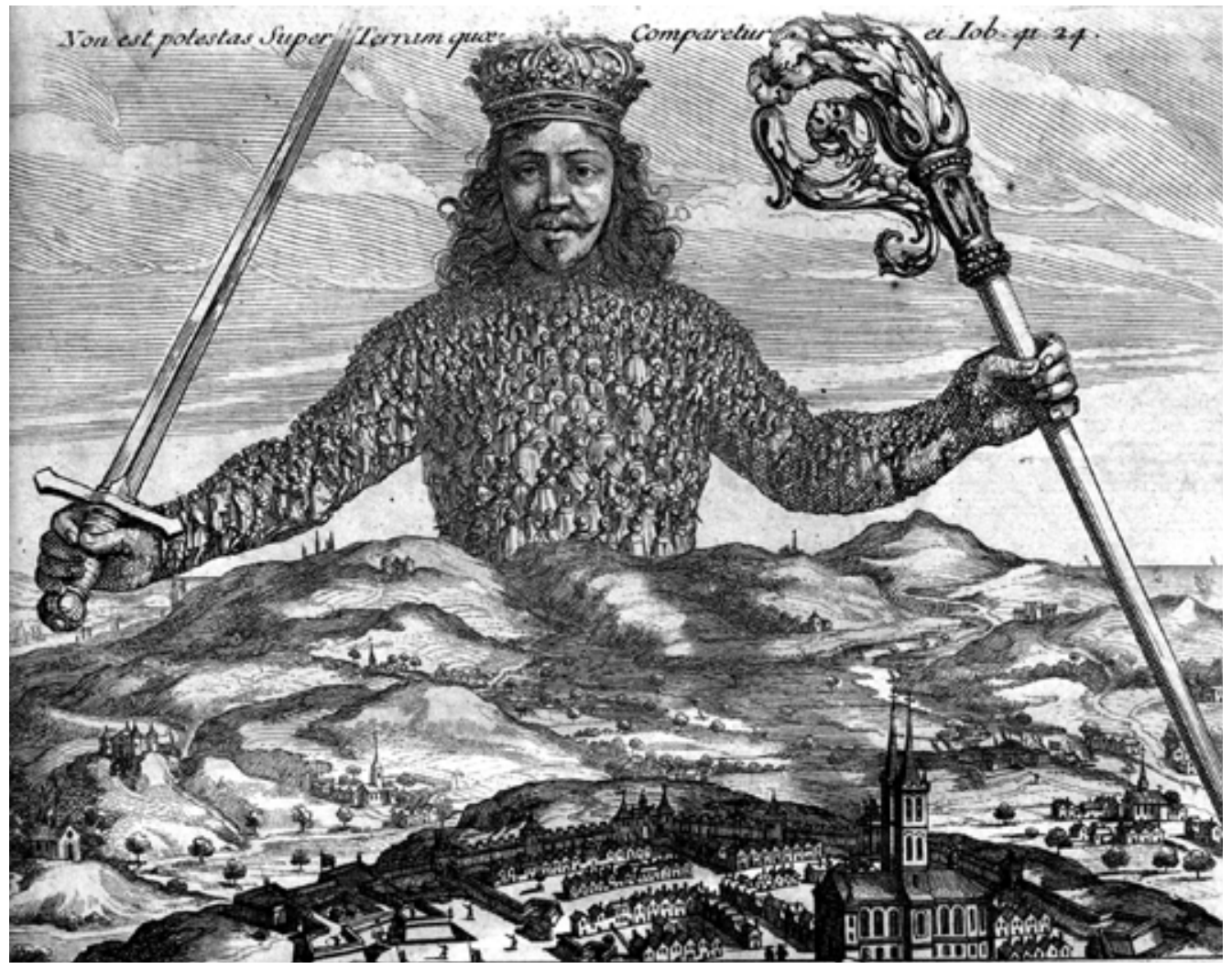

Detalhe do frontispício do livro Leviathan, de Thomas Hobbes; gravura de Abraham Bosse 


\section{RESUMO}

A partir da categoria de Estados rebeldes, que já foi utilizada ao longo dos últimos 50 anos para caracterizar Estados como Cuba, Irã, Iraque, Líbia e Coreia do Norte, e, recentemente, reciclada para se referir à maior ameaça contemporânea ao império estadunidense, a China, buscamos neste trabalho apresentar um chamado à sublevação anti-imperialista na forma de uma rebeldia institucional e de pensamento contra as imposições da ideia única. Pretendemos alcançar esse objetivo por meio da macrofilosofía e, mais especificamente, de reflexões sobre a obra Topologia da violência, do filósofo sul-coreano, mas de cosmovisão alemã, Byung-Chul Han, que propõe uma profunda interpretação sobre as novas formas de violência da contemporaneidade. De fato, buscamos justamente instar o sentimento da urgência de se retomarem em mãos próprias os destinos do Estado de direito, e do nosso Estado brasileiro, em particular. Isto é, de se repolitizarem todas as instâncias que o domínio imperial sub-repticiamente vem despolitizando e desideologizando. Para tal imensa e instigante tarefa, procuramos retomar um termo do próprio império, que pejorativamente denuncia aqueles poucos Estados no mundo que ainda ousam se colocar contra o seu domínio absoluto: Estados rebeldes. Ressignificada, a rebeldia estatal se coloca como desafio de criatividade para a reconfiguração dos diversos momentos do Espírito Objetivo que a sanha imperial pela ocultação da violência envolvida nos mecanismos de seu próprio domínio acabou por estilhaçar.

Palavras-chave: Estados rebeldes. Macrofilosofia. Topologia da violência. Poder.

\section{ABSTRACT}

From the category of rogue States, which has been used over the last 50 years to characterize States like Cuba, Iran, Iraq, Libya and North Korea, and recently recycled to refer to the greatest contemporary threat to the US empire: China, we seek in this paper to present a call for anti-imperialist uprising in the form of an institutional and thought rebellion against the impositions of the pensée unique. This aim is to be achieved through macrophilosophy and, more specifically, through the reflections on the book Topology of violence by the South Korean philosopher, albeit of German cosmovision, Byung-Chul Han, who proposes a deep interpretation of the new forms of violence in contemporary society. In fact, we seek precisely to arise the sense of urgency to take back into one's own hands the destiny of the Rechstaat, and of our Brazilian State in particular. To re-politicize all the instances that imperial domination has surreptitiously depoliticized and de-ideologized. For this immense and instigating task, we seek to take up an expression used by the empire itself, which pejoratively denounces those few States in the world which still dare to stand against its absolute domination: rogue States. Re-signified, State rebellion is posed as a challenge of creativity for the reconfiguration of the various moments of the objective spirit that the imperial zeal for concealing the violence involved in the mechanisms of its own domination ended up shattering.

Keywords: Rogue States. Macrophilosophy. Topology of violence. Power. 


\section{CONSIDERAÇ̃̃ES INICIAIS}

Se o mundo ficar pesado

Eu vou pedir emprestado

A palavra poesia

Se o mundo emburrecer

Eu vou rezar pra chover

Palavra sabedoria

Se o mundo andar pra trás

Vou escrever num cartaz

A palavra rebeldia

Se a gente desanimar

Eu vou colher no pomar

A palavra teimosia

Se acontecer afinal

De entrar em nosso quintal

A palavra tirania

Pegue o tambor e o ganzá

Vamos pra rua gritar

A palavra utopia

Jonathan Silva, "Samba da utopia"

A intuição artística é com frequência um ponto de partida claro e significativo do Zeitgeist, o espírito-do-tempo que nos circunda e que, mudando incessantemente, deixa-se pressentir no fazer da arte como manifestação imediata do Absoluto mesmo². É significativo que palavras de ordem se expressem assim em uma canção tanto como em uma necessária filosofia do Estado que urge ser trazida à consciência para ter possibilidade de se efetivar enquanto tal (HORTA, 2006). A arte da poesia e o saber da filosofia se aliam então em atitude rebelde e renitente, teimosamente obstinadas em se opor à tirania (ou a toda forma de despotismo),

Música gravada em 2018 e lançada às vésperas da eleição presidencial daquele mesmo ano.

2 "A figura desse saber [Absoluto] enquanto imediata (o momento da finitude da arte) por um lado é um dissociar-se, em uma obra de ser-aí exterior comum, no sujeito que a produz e no sujeito que a contempla e venera; por outro lado, é a intuição e representação concretas do espírito em si absoluto como do ideal." (HEGEL, 1995, p. 341) 
especialmente ao mais exemplar dos despotismos de nossos tempos - o império do pensamento único3 - , tendo por horizonte teleológico a própria utopia ocidental por excelência; isto é, a Liberdade conforme sua expressão política superior, a democracia (SALGADO, 1998; 2007).

O assim chamado império do pensamento único, frequentemente compreendido como a expressão mais acabada do domínio do capitalismo de mercado em sua expressão neoliberal, exerce seu implacável domínio praticamente sem sofrer resistências desde os eventos que levaram à queda do muro de Berlim, à extinção do dito "comunismo real" e à ascensão do conjunto de dogmas conhecidos por "Consenso de Washington"4. Significativamente, afirmará Han em um sentido ainda mais geral, em um prenúncio das questões de que aqui trataremos: "A violência de hoje nos toca muito mais a partir do conformismo do consenso do que do antagonismo do dissenso. Assim, contra Habermas, podemos falar de violência do consenso." (HAN, 20I7a, p. I3I)

Conjuntamente, esses movimentos históricos, usualmente compreendidos sob a chave do chamado neoliberalismo, penetraram nas consciências dos Estados e dos sujeitos como a expressão plena de um verdadeiro império que, entretanto, reluta em apresentar-se prontamente como o império de um povo, organizado em um Estado, sobre os demais, e rasteja subcutaneamente como um suposto consenso impositivo em torno de ideias que se apresentam conjuntamente como a posição de um impessoal "mercado"s.
A "desconflitualização" [...] deve ser vista em conexão com a positivação geral da sociedade, que desencadeia uma desideologização da mesma. $\mathrm{O}$ aconteci- mento político já não é mais determinado pelo antagonismo de ideologias ou classes, que já se tornou arcaico. Contudo, a positivação da sociedade não elimina a violência. Esta não parte apenas da negatividade do antagonismo ou do conflito, mas também da positividade do consenso. A totalidade do ca- pital, que ora parece absorver tudo, apresenta uma violência consensual (HAN, 20I7a, p. 78).

Sob império- seja o Macedônico, que dominou os gregos no período que conhecemos como helenismo, seja o da "ideia única" do capitalismo contemporâneo - , os sujeitos, quando seu Destino comum está vedado à livre autoconsecução política, sempre tendem a se voltar à apatia. Contra tal situação de terrível falta de perspectiva, se apegam ao único resquício de suposta liberdade, que é dado justa-

"Esvaziar a ideologia, por fim, é o nefasto legado dos últimos 20 anos, especialmente desde a crise ideológica recorrente depois da queda do Muro de Berlim, em novembro de 1989: castrar o debate, castrar o discurso, castrar a polêmica. Eis aí o terreno fértil para as teorias atuais do chamado pensamento único." (HORTA, 2011, tradução nossa). Sobre o tema, cf. Mayos Solsona (2000, p. 17-40).

Para a expressão mais contundente dessa posição, v. Fukuyama (1992). Para uma crítica elucidativa, cf. Horta, Freire e Siqueira (2012)

Para uma defesa clara da coexistência do império do mercado e a assim chamada pax americana, v. Klein (2008, passim). 
mente pela percepção da subjetividade livre, isto é, manifesta como aparentemente livre de toda restrição exterior, e que contemporaneamente se apresenta na ideia de individualidade ${ }^{6}$.

Se tal era verdade nas manifestações do helenismo grego durante a dominação daquele orgulhoso povo pelo Império Macedônico, não seria diferente no império mundial contemporâneo. Entretanto, as formas específicas de manifestação, tanto da violência imperial quanto das respostas subjetivas ou mesmo políticas, se modificam em face dos diferentes tempos e contextos. A história, afinal, não se repete, nem como tragédia nem como farsa, mas transmuta-se sempre em novas manifestações, absolutamente inovadoras, ainda que com os traços gerais que nos caracterizam - como humanidade ou como civilização. Percebe-se assim que os acontecimentos históricos se espiralam de forma a conservar características intrínsecas de uma certa universalidade que, entretanto, comporta sempre os traços únicos e característicos de uma nova particularidade. Assim se modifica, por exemplo, a forma da violência no contexto contemporâneo:

Ela [a violência] se desloca do caráter visível para o invisível, do frontal para o viral, da força bruta para a medial, do real para o virtual, do físico para o psíquico, do negativo para o positivo, e volta a se recolher para espaços subcutâneos, subcomunicativos, capilares e neuronais, de modo que surge a falsa impressão de que ela teria desaparecido. Atualmente torna-se totalmente invisível quando se confunde e se identifica com seu contraponto: a liberdade. Assim, a violência marcial dá lugar ao poder anônimo des-subjetivado e se esconde no poder sistêmico que coincide com a sociedade (HAN, 20I7a, p. 7-8).

Contra a apatia de uma vida imersa no cotidiano e que se arrasta, ainda que marcada hoje por uma agitação hiperpositiva da ação irrefletida característica de uma sociedade de desempenho ${ }^{7}$, a tarefa que se impõe é justamente a urgente emergência de alguma rebeldia ${ }^{8}$. Mas uma rebeldia para o tempo presente, que não se manifesta necessariamente apenas como a ação do sujeito rebelde contra o sistema-império que o violenta e oprime, mas talvez também como a reabilitação restauradora da negativi-

\footnotetext{
"Sabemos que Hegel lamenta em vários passos de sua extensa obra a implosão da comunidade ética grega, substituída pela arbitrariedade dos déspotas helenísticos e posteriormente pelo poder irresistível do Imperador de Roma. Tal processo gerou grande insegurança no horizonte mental dos indivíduos, que passaram então a depender do arbítrio de alguns poucos e não mais da própria vontade. Em um ambiente assim só resta ao homem cultivado refugiar-se em si mesmo e buscar a segurança da norma moral em sua interioridade, opondo-se desse modo ao caos jurídico-normativo gerado pelo esmigalhamento do ideal autonômico da pólis. Não é por acaso que na época helenística assistimos ao surgimento do indivíduo enquanto figura oposta ao cidadão, assim como à substituição da liberdade política pela liberdade interior." (COSTA MATOS, 2010, p. 377)

7 "A sociedade de desempenho de hoje, com sua ideia de liberdade e desregulamentação, vai derrubando de forma massiva barreiras e proibições que caracterizavam a sociedade disciplinar; a derrubada da negatividade deve incrementar o desempenho. Dirige-se à eliminação universal das barreiras e limites, à promiscuidade geral, da qual não surge qualquer energia repressiva." (HAN, 2017a, p. 68)

8 Um primeiro grito de atenção para essa urgência, em sentido bastante próximo àquele para o qual aqui chamamos a atenção, foi manifestado em Horta (2012).
} 


\section{Para além da rebeldia \\ subjetiva do pensamento, deve emergir um outro tipo de rebeldia, mais ampla e mais potente, pois o sujeito rebelde apresenta limitações práticas reais bastante perceptíveis}

dade do Espírito Objetivo como instância privilegiada de manifestação de uma rebeldia coletiva e comunitária que se exprime como autodeterminação e que faz amplo uso da imaginação como forma de se opor à ideia única9.

O chamado à rebeldia do pensamento como forma de combate à tirania do pensée unique não é propriamente recente ${ }^{\mathrm{Io}}$, mas ganha relevo e centralidade no pensamento de Roberto Mangabeira Unger, cuja reflexão busca, segundo ele próprio, "provocar rebeldia intelectual e animar a resistência ao colonialismo mental" (UNGER, 20I8, p. I4). Mas, para além da rebeldia subjetiva do pensamento, deve emergir um outro tipo de rebeldia, mais ampla e mais potente, pois o sujeito rebelde apresenta limitações práticas reais bastante perceptíveis. Assim, a ideia de Estados rebeldes ${ }^{\mathrm{II}}$ talvez seja capaz de ampliar essa dimensão da rebeldia para o nível do Espírito Objetivo

9 A essa rebeldia deve necessariamente anteceder um chamado e uma busca pela consciência que manifestamos recentemente em Henriques e Carvalho (2020). O texto inspira-se em outro chamado igualmente essencial à consciência da elite intelectual, assim expresso: "Nenhum autor do hoje deixa de conter no âmago do seu pensamento toda a tradição que o antecedeu, e portanto: a) compreender um filósofo exige aprender a situá-lo como ponto de chegada de uma trajetória de ideias e contradições, e b) nenhum filósofo consciente dos seus desafios pode deixar de indagar-se a respeito de suas próprias tradições e seus próprios fundamentos — dando renovado sentido ao dístico de Apolo em Delfos e tornando o 'conhece-te a ti mesmo' em um exercício de reconstrução das linhas históricas que eclodem em ti como ponto de chegada da história toda." (HORTA, 2017, p. 75)

10 Já o santo protetor das "Ciências do Estado", Thomas Morus, percebia a importância da rebeldia para a constituição de um espírito verdadeiramente orgulhoso. Embora não discuta propriamente a rebeldia em termos de império, Morus aponta os efeitos nefastos da miséria e da pobreza (e poderíamos acrescentar os efeitos da opressão, da tirania e da violência) sobre o espírito: "A riqueza e a liberdade tornam as pessoas menos tolerantes com as ordens duras e injustas enquanto, por outro lado, a pobreza e a miséria embotam o espírito, tornando-as pacientes e retirando do oprimido o espírito orgulhoso da rebeldia." (MORUS, 2004, p. 35)

11 A noção de Estados rebeldes aqui desenvolvida é uma subversão da estratégia estadunidense de tachar os Estados desalinhados ao pensamento único de rogue States. O termo, que já foi utilizado ao longo dos últimos 50 anos para caracterizar Estados como Cuba, Irã, Iraque, Líbia e Coreia do Norte, foi recentemente reciclado para se referir à maior ameaça contemporânea ao império dos EUA, a China. Assim, buscamos aqui apresentar o termo Estados rebeldes como um chamado à sublevação anti-imperialista na forma de uma rebeldia institucional e de pensamento contra as imposições do pensamento único. 
- ora largamente fraturado, como veremos -, na forma que, aliás, também propõe Unger, visto que essa é uma instância mais privilegiada e mais capaz de se impor com muito maior veemência ao império dominante do que o mero sujeito rebelde. Ora, o sujeito por si só jamais poderá colocar-se em estado de bravura perante o mundo, assim, será sempre incapaz de responder ao chamado hegeliano à consciência e à ação intencional digna da História mundial ${ }^{12}$.

\section{LEVIATÃ ACORRENTADO}

Cumpre-te agora, ó Vulcano, pensar nas ordens que recebeste de teu pai, e acorrentar este malfeitor, com indestrutíveis cadeias de aço, a estas rochas escarpadas. Ele roubou o fogo — teu atributo, precioso fator das criações do gênio, para transmiti-lo aos mortais! Terá, pois, que expiar este crime perante os deuses, para que aprenda a respeitar a potestade de Júpiter, e a renunciar a seu amor pela Humanidade.

Sófocles, "Prometeu acorrentado"

Conforme já expressamos, a genealogia da violência enquanto história das mudanças topológicas do caráter da violência, que empreende Byung-Chul Han, tende a avançar as reflexões genealógicas de outros pensadores, com elas dialogando ${ }^{13}$, para discutir as características centrais da contemporaneidade, que retraça em tintas

12 A conclamação de Hegel em sua Enciclopédia das ciências filosóficas, ao final da apresentação do Estado como cumeada da eticidade do Espírito Objetivo, exige uma resposta estatal totalmente diversa daquela possível ou mesmo imaginável ao sujeito particular: "Essa independência faz do conflito entre elas [as diferentes totalidades éticas, i.e., os Estados] uma relação de violência, um estado de guerra, para o qual a situação universal se determina em vista do fim particular da conservação da autonomia do Estado perante os outros, em um estado de bravura." (HEGEL,1995, p. 318). Não que desconheçamos a potência do sujeito particular quando instado a defender sua própria autonomia e a de seu Estado diante do invasor clássico, como percebido por Carl Schmitt ao descrever a potência do guerreiro partisan (SCHMITT, 2008, passim). Contudo, ante os modos de violência da sociedade do desempenho, esse sujeito está completamente absorto no esforço de submeter-se a si mesmo, incapaz de sequer supor que se encontra sob domínio de uma instância de poder a ele alheia: "A sociedade de desempenho, enquanto sociedade de doping, não estabelece diferença alguma entre classes e sexo. Tanto os topdogs quanto os underdogs são atingidos do mesmo modo pela ditadura do desempenho e da otimização. Todos os membros da sociedade acabam sendo atingidos pelo burnout; parece que nos transformamos em zumbis do desempenho e da saúde, sendo que as vítimas dessa violência sistêmica não são apenas os homini sacri, enquanto excluídos, mas inclusive o sujeito de desempenho incluído no sistema, enquanto soberano, empreendedor de si mesmo, que não está submisso a ninguém e que, nesse sentido, é livre e, ao mesmo tempo, homo sacer de si mesmo. A violência sistêmica não é uma violência da exclusão, ao contrário, ela transforma todos em incluídos, sim; como presidiários do sistema, obrigando-os a se auto-explorarem." (HAN, 2017a, p. 168)

13 Embora alguns autores já identifiquem traços de uma perspectiva genealógica no pensamento de Spinoza (2009), a ideia do pensamento genealógico se torna particularmente bem delineada na história da filosofia desde a vinda a lume da obra Genealogia da moral, de Nietzsche (NIETZSCHE, 2013). Essa espécie de olhar sobre a história voltaria a ser amplamente arregimentada por Foucault em suas História da sexualidade e História da loucura (FOUCAULT, 1988; 1972). 
propriamente macrofilosóficas ${ }^{14}$ para com isso lançar luz sobre nossa realidade, permitindo sua emergência à consciência das particularidades que conferem o aroma próprio de nossos tempos. Erige-se, por isso, o inegável incômodo do pensador diante de uma sociedade que aclama, como panaceia, justamente os elementos que causam a morbidade patente de sua existência.

O sujeito de desempenho entrega-se à livre coerção para a maximização do desempenho. Assim, explora a si próprio. A autoexploração é mais eficiente do que a exploração alheia na medida em que é acompanhada por um falso sentimento de liberdade; o explorado é, ao mesmo tempo, quem explora. A exploração acontece, aqui, sem dominação; é isso que perfaz a eficiência da autoexploração. $\mathrm{O}$ sistema capitalista transmuta-se da exploração alheia para a autoexploração, do dever para o poder, para acelerar-se. Em virtude de sua liberdade paradoxal, o sujeito de desempenho é, ao mesmo tempo, agressor e vítima, senhor e escravo. Liberdade e violência não se distinguem aqui; o sujeito de desempenho que se apresenta como soberano de si, como homo liber, mostra ser um homo sacer. O soberano da sociedade de desempenho é, ao mesmo tempo, o homo sacer de si mesmo. Em uma lógica paradoxal, na sociedade de desempenho o soberano e o homo sacer se condicionam mutuamente, mas também são idênticos (HAN, 2017a, p. 262-263).

É precisamente nesse sentido que Han busca descrever as consequências de uma sociedade que exorta tudo e todos à mais completa positividade e transparência (HAN, 20I7b), vivenciadas de forma particularmente patente no ambiente liso (HAN, 20I9a, p. 7) e totalmente informacional do universo digital, que é incapaz de formar comunidades lógicas, se comportando mais propriamente como um enxame desordenado, mas que hoje se espraia para todas as instâncias da vida ${ }^{15}$. Não apenas o ambiente digital se vê vinculado a esse estilhaçamento do comunitário; Han também compreende que a própria estrutura da sociedade contemporânea exorta os sujeitos a uma individualização absoluta, gerando a incapacidade de percepção do outro como um efetivamente alter a partir do qual é possível ao ego se constituir (HAN, 2017c). Nesse "inferno do igual”" ${ }^{\prime 6}$ os sujeitos parecem deixar de sofrer imposições externas

\footnotetext{
14 "A análise macrofilosófica [...] consiste em uma perspectiva aberta que exige muito mais trabalho, colaboração de distintos âmbitos acadêmicos, além de - por óbvio - abertura e grandeza de perspectivas" (MAYOS SOLSONA, 2016, p. 57, tradução nossa).

15 "O consumidor compra aquilo que the apraz. Ele segue as suas inclinações individuais. $\bigcirc$ Curtir é o seu lema. Ele não é um cidadão. A responsabilidade pela comunidade caracteriza o cidadão. Ela falta, porém, ao consumidor. Na ágora digital, onde local de eleição e mercado, pólis e economia se tornam o mesmo, eleitores se comportam como consumidores. [...] Também o governar se aproxima do marketing. O questionário político se iguala, então, a uma pesquisa de mercado. As opiniões eleitorais serão descobertas por meio de data mining [mineração de dados]. [...] Aqui não somos mais agentes ativos, não somos cidadãos, mas sim consumidores passivos." (HAN, 2018, p. 118-119) Sobre esse tema e seus desdobramentos, que Han por vezes trata sob a perspectiva de uma "teatrocracia", ver também a ideia de uma "sondocracia", desenvolvida em Souza (2015).

16 Han toma o termo de empréstimo a Baudrillard: "Já não é o inferno dos outros, é o inferno do Mesmo." (BAUDRILLARD, 1992, p. 130).
} 
para se desenvolverem plenamente como os sujeitos de desempenho da contemporaneidade neocapitalista que se esgotam a si mesmos na mais absoluta autoexploração, enquanto empreendedores de si mesmos ${ }^{17}$.

Contra esse paradigma totalitário, embora pouco identificável nas chaves normais da percepção da ameaça e do inimigo, Han propõe o resgate do erotismo como uma atitude filosófica e rebelde de reopacificação erótica do mundo (HAN, 20I9a), que restaure a dimensão da negatividade contra sua denúncia desta sociedade de hiperpositividade, que a tudo vai positivando e englobando sem qualquer perspectiva efetiva de dialogicidade, e, sobretudo, sem qualquer consideração com a necessária "dialeticidade" do próprio real $(\mathrm{HAN}, 2019 \mathrm{~b})^{18}$.

A sociedade da transparência é inimiga do prazer. Dentro da economia do prazer humano, prazer e transparência não conseguem conviver. A transparência é estranha à economia libidinosa, pois é precisamente a negatividade do mistério, do véu e da ocultação que aguilhoa o desejo e intensifica o prazer. Mas o sedutor joga com máscaras, ilusões e formas de aparência, e a coação da transparência aniquila espaços de jogo do prazer; a evidência não admite sedutor, mas apenas procedimentos (HAN, 20I7b p. 39).

Em sua intuição sobre a contemporaneidade, ganham especial relevo as discussões sobre o poder e sobre a violência ${ }^{19}$, como o ponto central, mais íntimo, da emergência de um novo paradigma que contrasta com todos os momentos anteriores da história humana por inverter a lógica das oposições que nortearam o sentido da cultura ocidental, especialmente aquela entre o Poder e a Liberdade ${ }^{20}$. Assim, o poder do império contemporâneo se evade de ser identificado em sua dominação pelo exercício de uma forma particularmente oculta (por sua absoluta transparência) de violência: a violência

17 "O excesso de positividade se manifesta também como excesso de estímulos, informações e impulsos. Modifica radicalmente a estrutura e economia da atenção. Com isso se fragmenta e destrói a atenção. Também a crescente sobrecarga de trabalho torna necessária uma técnica específica relacionada ao tempo e à atenção, que tem efeitos novamente na estrutura da atenção. A técnica temporal e de atenção multitasking (multitarefa) não representa nenhum progresso civilizatório. A multitarefa não é uma capacidade para a qual só seria capaz o homem na sociedade trabalhista e de informação pós-moderna. Trata-se antes de um retrocesso. A multitarefa está amplamente disseminada entre os animais em estado selvagem. Trata-se de uma técnica de atenção, indispensável para sobreviver na vida selvagem." (HAN, 2017d, p. 31-32)

18 Sobre a "dialeticidade" do real, cf. a célebre expressão de Hegel na sua Filosofia do Direito, em que o real é expresso como efetivo na tradução para o português, e que afirma: "O que é racional, isto é efetivo; e o que é efetivo, isto é racional." (HEGEL, 2010, p. 41) Sobre esse tema, ver também o inspirado Horta (2013)

19 Para distingui-los, dirá Han: "Tanto o poder quanto a violência servem-se de uma técnica de subjugação, de 'dobrar o outro'. O poder faz uso desse expediente até que o outro se submeta; a violência o faz de tal modo que o outro 'quebra'." (HAN, 2017a, p. 138)

20 Essa tensão essencial é que leva Salgado a afirmar que "a história do pensamento ocidental é um embate entre a liberdade e o poder" (SALGADO, 1998). Também Han é consciente da necessidade de se reabilitar o poder para seu projeto de reerotização da vida: "O poder não leva a menos desejo, mas a mais. Relações de vigilância viram contatos de indução que eletrizam a superfície da pele. 0 poder forma um corpo sexual que incansavelmente fala e significa. A semântica do desejo sexual está ligada frequentemente à semântica do poder. O corpo nunca é nu. Na verdade, ele está misturado com significados que, segundo Foucault, são efeitos do poder." (HAN, 2019c, p. 67) 
da positividade, que se transveste de absoluta liberdade subjetiva. "A história da violência se locupleta nessa coincidência de agressor e vítima, de senhor e escravo, de liberdade e violência." (HAN, 20I7a, p. 265, grifos originais)

Assim, uma das teses centrais do autor é justamente a mudança do paradigma da violência que ele observa em pelo menos três momentos da modernidade: a violência física da assim chamada sociedade da soberania; a violência disciplinar da sociedade disciplinar; e a violência da positividade da sociedade do desempenho ${ }^{21}$. A essa mudança da topologia da violência se relacionam também suas formas de expressão mais marcantes:

A decapitação na sociedade da soberania, a deformação na sociedade disciplinar e a depressão na sociedade de desempenho são estágios da mudança topológica da violência, que é sempre mais internalizada, psicologizada e, assim, acaba se tornando invisível. Ela vai se livrando mais e mais da negatividade do outro ou do inimigo, tornando-se autorreferente ${ }^{22}$ (HAN, 2017a, p. 10-11).

Nessa genealogia, uma outra modificação significativa se inscreve com centralidade. Ao empreender uma arqueologia da violência, Han percebe que ela possui, inicialmente, um caráter religioso. "A violência é, igualmente, quiçá, a primeira experiência religiosa"(HAN, 20I7a, p. 3I). A violência da natureza contra a qual uma comunidade humana se organizava conferia o sentido da coesão internamente edificada, enquanto a violência de outros grupos humanos que a ameaçavam dava o sentido de uma coesão também externamente justificada. A violência sofrida pela natureza impelia à aproximação e conexão entre os membros da comunidade tanto quanto as disputas entre comunidades e a violência ritual (ou por vezes mesmo sacrificial) usualmente atreladas a elas.

A ação religiosa consistia principalmente em suavizar a violência e impedir o seu desencadeamento, quiçá fazendo uso da própria violência. Todas as características violentas que se encontravam dentro de uma sociedade eram

21 Também o poder é percebido por Han em sua modificação em três momentos: o poder coercitivo, o poder disciplinar e o "Poder como Liberdade" (ou Poder livre); mas, ao contrário da violência, o poder é por ele percebido em seu sentido positivo, de organização e administração da vida. Nesse sentido, é notável sua reprimenda a Agamben: "Agamben [...] toma conhecimento do poder tematizado por Foucault apenas de forma negativa. Do poder ele retira novamente a positividade apontada constantemente por Foucault em sua análise do poder. Com isso, faz coincidir o tal do 'biopoder' — cuja intencionalidade, segundo Foucault, não é a ameaça da morte, mas o gerenciamento ou organização da vida - com aquela violência que faz surgir uma 'vida absolutamente matável', uma tal mediação legal da vida nua, ou seja, homo sacer. Foucault interpreta o 'biopoder', em contrapartida, como aquele acontecimento que conduz a vida através de normas e de normalizações, ou seja, também estruturante e revestido de sentido. Ele está investido não apenas de exclusão e banimento, mas também de administração e organização." (HAN, 2019c, p. 62, nota). A referência central da crítica de Han é a Agamben (2002).

22 Sobre esse mesmo tema, desenvolve à frente na mesma obra: "É inerente à sociedade pré-moderna da soberania a violência da decapitação; seu medium é o sangue. A sociedade disciplinar moderna é, em grande medida, uma sociedade da negatividade, sendo regida e dominada pela coerção disciplinar, isto é, pela 'ortopedia social'. Sua forma de violência é a deformação. Mas nem a decapitação nem a deformação estão em condições de descrever a sociedade de desempenho pós-moderna. Ela é dominada por uma violência da positividade, que confunde a liberdade e a coerção. Sua manifestação patológica é a depressão." (HAN, 2017a, p. 183-184) 


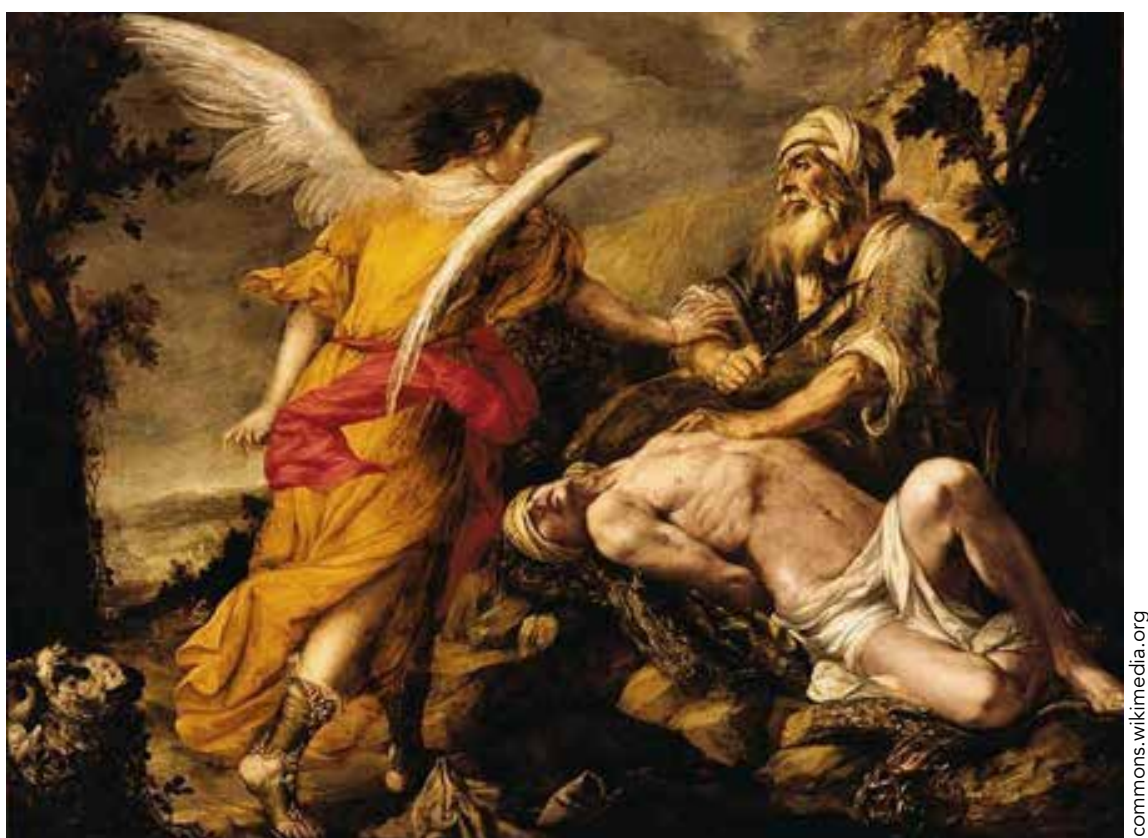

O sacrifício de Isaac (1657-1659), de Juan de Valdés Leal. Óleo sobre tela

descarregadas sobre a vítima reconciliadora e, com sua morte, eram conduzidas para fora da sociedade (HAN, 20I7a, p. 34).

Assim, a violência ritual se imbui de um caráter próprio do poder que a torna produtiva, como ordenadora e administradora da própria comunidade, o que a posiciona com centralidade dentro desta ${ }^{23}$. Nesse sentido, a violência religiosa dos primeiros povos é a mais cabal prova da abnegação da subjetividade em prol da sociedade, podendo ser mesmo tomada como antítese da violência da positividade, na qual o sujeito-indivíduo simultaneamente se autoentroniza e se autoviolenta como pura reafirmação de si mesmo enquanto instância supostamente produtora de realidade, um trabalho que o sujeito isolado dificilmente poderá realizar de fato - e, caso o pudesse fazer, este se provaria um exercício totalmente fechado em si mesmo, como um ermitão que morresse ao relento e nem sequer notícias de sua morte fossem dadas à História. Esse é um sentido também próximo da interpretação de Hegel acerca do tema do sacrifício, que ele compreende como podendo ter algumas significações:

O sacrifício implica imediatamente o abandono de uma finitude imediata no sentido de atestar que ela não deve me pertencer e que eu não a quero conservar para mim; portanto, o sacrifício, segundo esse ponto de vista da autoconsciência religiosa, é um autêntico sacrifício. [...] O sacrifício não consiste em uma conversão do ânimo, do coração e das inclinações naturais, no sentido de os quebrantar. Em vez disso, o sujeito se encontra em posse

23 "A práxis religiosa da violência não é apenas reativa e preventiva, mas também ativa e produtiva." (HAN, 2017a, p. 35) 
imediata do que ele é para si, e o abandonar de sua finitude no culto consiste no abandono de uma posse imediata e de um ser-aí natural. [...] Agora o sacrifício pode ser, mais precisamente, um mero sacrifício de veneração e de louvor, o testemunho de que não me reservo nada de próprio, senão que o abandono ao pensar-me em relação com o Absoluto. Aquele perante o qual se abandona a posse não deve enriquecer por isso, senão que o sujeito apenas toma consciência de superar a separação, e, nessa medida, seu ato é absolutamente um ato de alegria (HEGEL, I998, p. I.212-I.2I3, tradução nossa).

Daquela violência ritual que produzia sociabilidade contra um mundo violento em si mesmo, de fenômenos naturais pouco compreensíveis e implacáveis, a topologia da violência foi se modificando como violência coercitiva até a emergência das sociedades disciplinares descritas e denunciadas por Foucault (I999). A rigor, entretanto, como já pudemos perceber, lá a violência disciplinar também organizava a vida das sociedades e produzia um viver ordenado externamente, isto é, produzia-se como manifestação de um Espírito Objetivo que imbuía de negatividade a violência exercida, fosse pelos Estados ou pelos impérios ${ }^{24}$. É de se notar, entretanto, que justamente esse caráter de objetividade externa que ordenava a violência coercitiva e disciplinar confere aos sujeitos (mormente onde vigorou ou vigora ainda um autêntico Estado de direito) a possibilidade de se rebelar politicamente de diferentes formas e de contribuir para reconfigurar o próprio Espírito Objetivo e, por meio dele, também suas formas de violência legítimas.

Nesse sentido o sujeito rebelde talvez possa ser compreendido como o tipo ideal da genialidade livre, já que foi instado à plena obediência (pelas violências coercitivas e disciplinares) e contra ela se rebelou. Mas é notável justamente que o sujeito rebelde não se revolte por meio da participação na apatia geral que exprimem aqueles sujeitos incapazes de definir seus próprios destinos. Ele é um agente político pleno, consciente da insuficiência de sua jornada enquanto sujeito isolado, e que propõe a mudança por diversas vias e a busca. Os sujeitos rebeldes são os mais profundos conhecedores do Espírito Objetivo que pretendem modificar, são conscientes de seus modos de ação e de violência, das quais com frequência já foram vítimas e de que

\footnotetext{
24 É válido registrar que esse caráter ordenador do Espírito Objetivo é reconhecido também por Hegel, inclusive a respeito do próprio Estado: "É bem verdade que no direito existe a possibilidade de uma imposição violenta, mas necessariamente ele não precisa se basear nela. Nesse sentido Hegel escreve que 'a representação imagina, muitas vezes, que a coesão do Estado se dá através da violência; mas o elemento aglutinador é só o sentimento fundamental da ordem que todos têm' [...]. A violência nada mantém coeso. A partir dela não se alcança estabilidade; pelo contrário, sua existência é sinal de instabilidade interior. Uma ordem jurídica que só pudesse se manter pelo emprego da violência seria muitíssimo frágil. [...] A violência se manifesta precisamente no momento em que o elemento 'sustentador' desaparece da ordem do Direito." (HAN, 2017a, p. 104-105) Os trechos de Hegel citados são do adendo ao parágrafo 268 da Filosofia do Direito, que pode ser conferido, embora com leves distinções de estilo dos tradutores, em Hegel (2021, p. 266). Para uma manifestação de semelhante compreensão no culturalismo jurídico brasileiro, em que o elemento sustentador é ainda mais claramente identificado na cultura de um povo, v. Saldanha (2003). Han chegará a uma conclusão similar: "Quanto menor for a diferença entre a vontade do detentor do poder e aquele que está submisso ao poder, mais estável será o poder." (HAN, 2017a, p. 120)
} 


\section{O sujeito rebelde encarou o sistema de frente, e se demorou nele - não o conhece ou reconhece simplesmente, ele efetivamente compreende o sistema contra o qual se coloca. Não o teme, mas o respeita pela força que ele possui e pela ordem que foi capaz de instituir. Sabe dos limites dele e dos seus próprios. É por isso que está em situação privilegiada de interação com aquela totalidade específica}

agora precisam mesmo evadir-se $\mathrm{e}^{25}$. Nas sociedades coercitivas e disciplinares, foram os sujeitos rebeldes quem, uma vez politicamente organizados e conscientes do modo particular em que uma sociedade estava organizada, se fizeram agentes de mudança ${ }^{26}$.

De essencial importância, devemos compreender que o sujeito rebelde encarou o sistema de frente, e se demorou nele - não o conhece ou reconhece simplesmente, ele efetivamente compreende o sistema contra o qual se coloca. Não o teme, mas o respeita pela força que ele possui e pela ordem que foi capaz de instituir. Sabe dos limites dele e dos seus próprios. É por isso que está em situação privilegiada de interação com aquela totalidade específica. A rebeldia permite deixar de apenas olhar ou integrar o Espírito Objetivo e passar então a interagir conscientemente com ele,

$25 \bigcirc$ sujeito rebelde estabelece uma relação efetivamente dialética com o poder, compreende os pontos positivos e negativos dele e com ele se relaciona de forma consciente: "A violência se expressa, aqui, como uma violência de fora, que recai sobre mim, me sobrepuja e me rouba, assim, a liberdade. Ela penetra em meu interior sem meu consentimento. Mas nem toda influência vinda de fora é considerada violência. No momento em que lhe dou anuência e a incluo em minha ação, i.e., no momento em que construo uma relação com ela, já não é violência. Relaciono-me com ela livremente; confirmo-a como conteúdo de mim mesmo. Onde essa apropriação interiorizadora mostra ser absolutamente impossível eu a experimento como violência." (HAN, 2017a, p. 137-138)

26 Assim também se podem compreender as prolíficas heresias do medievo, justamente como a rebeldia política de grupos católicos contra o que compreendiam como violência doutrinária. Nesse sentido, novamente a inspiração da arte, agora pela pena de Umberto Eco, nos guia: "Mas vós sabeis muito bem que, assim como eles não distinguem entre Igreja búlgara e sequazes do padre Liprando, muitas vezes também as autoridades imperiais e seus sustentadores não distinguiram entre espirituais e hereges. Não raro grupos guibelinos, para derrotar seu adversário, sustentaram entre o povo tendências cátaras. A meu ver fizeram mal. Mas o que sei agora é que os mesmos grupos, muitas vezes, para desembaraçar-se desses inquietos e perigosos adversários por demais 'simples', atribuíram a uns as heresias de outros, e mandaram todos para a fogueira." (ECO, 1995, p. 181) 
inclusive contribuindo para eventualmente (re)moldá-lo ${ }^{27}$. Mas para se rebelar é preciso conhecer a mudança na topologia da violência que ora se exerce e ter consciência dela, pois as manifestações mais explícitas e cruentas de violência vão se tornando crescentemente odiosas aos olhos de uma sociedade hiperpositiva.

A crescente positivação da sociedade também vai transformando aquele tipo de violência, tanto física quanto psíquica, em algo deplorável. Mas isso não significa o fim da violência, pois ela não parte apenas da negatividade do outro, mas também do excesso de positividade. A violência da positividade não é apenas privativa, mas saturativa; não é apenas executiva, mas também exaustiva. Ela não se baseia na exclusão, mas na exorbitância; não se expressa como repressão, mas como depressão (HAN, 20I7a, p. I5I).

Assim, bem compreendida a mudança na topologia da violência, abre-se a possibilidade de repensar o papel da rebeldia na contemporaneidade, quando "o sistema capitalista transmuta-se da exploração alheia para a autoexploração, do dever para o poder, para acelerar-se" (HAN, 2017a, p. 263). A hiperpositividade da violência nada mais é que uma forma de um poder imperial se evadir de ser reconhecido como tal e, portanto, de ser desafiado. Desvelado esse poder, temos a oportunidade de repensar nossa relação com ele em novas bases. Para tanto, contudo, é preciso compreender ainda mais esse processo ${ }^{28}$. Em específico, é essencial que percebamos o conjunto de processos que levaram a essa situação em que os Estados são incapazes de se colocar no mundo autonomamente e se autodeterminarem plenamente — por ora, seguem Leviatãs acorrentados.

\section{LEVIATÃ LIBERTO}

Com efeito, não foi uma ameaça, apenas: a terra põe-se a tremer... O soturno ronco já se faz ouvir... Turbilhões de poeira se erguem... todos os furacões desencadeados parece que estão

\footnotetext{
$\overline{27}$ Para tanto, é significativo notar que o sujeito rebelde vence o medo da morte, justamente esse medo de que a economia do capital faz uso para perpetuar-se como objeto de desejo numa sociedade contemporânea amplamente desencantada: "Também a economia do capital indica uma semelhança gritante em relação à economia arcaica da violência. Em lugar do sangue ela faz fluir dinheiro; há uma proximidade essencial entre sangue e dinheiro. E assim, o capital se comporta como mana moderno; quanto mais capital se possui mais se imagina ser poderoso, invulnerável, imortal. [...] Dinheiro ou capital são, portanto, recursos contra a morte." (HAN, 2017a, p. 45-46)

28 A tese de Han acerca da possibilidade de escape dessa situação passa pela categoria da amabilidade (Freundlichkeit), que ele desenvolve em sua plenitude em sua tese sobre Hegel ainda não traduzida para o português (HAN, 2019d), mas que vem rapidamente esboçada em outros de seus escritos: "Para se libertar da roda de hamster, que gira cada vez mais rápido ao redor de si mesma, seria necessário restabelecer a relação com o outro, e quiçá para além do esquema amigo/inimigo schmittiano, ligado à violência da negatividade. Assim, faz-se necessária outra construção, uma reconstrução do outro que não desencadeie qualquer tipo de defesa imunológica destrutiva. Deveria ser possível estabelecer uma relação com o outro na qual o 'deixasse estar', confirmando-o em sua alteridade, em seu ser-assim. Esse sim ao assim se chama amistosidade [Freundlichkeit]. Ela não consiste em deixar o outro passivo, indiferente, mas é uma relação ativa, participante no seu ser-assim." (HAN, 2017a, p. 102-103)
} 
contra mim! Contra mim, é que Júpiter desfecha tão horrendo cataclismo. Ó minha augusta mãe: ó tu, divino éter que cercais o universo de luz eterna... vede que injustos tormentos me fazem sofrer!

Sófocles, "Prometeu acorrentado"

Ressoa com persistência em torno de nosso debate o já apresentado clamor de Hegel para que os Estados se coloquem, "perante os outros, em um estado de bravura" (HEGEL, 1995, p. 318). Entretanto, o império do pensée unique, forma acabada de uma hegemonia estadunidense que se desterritorializou como parte dos processos mesmos de positivação da violência, que, não podendo ser prontamente associada a um "sujeito" - um povo, uma cidade, um Estado que exerce o poder para o domínio propriamente dito - , torna-se mais difícil de ser também combatida, ganha em efetividade da dominação e também atua para impedir a consciência de si dos Estados"29. "Diante do igual não é possível haver amistosidade nem hostilidade, nem sim nem não, nem saudação nem rechaço" (HAN, 20I7a, p. I03). Sem tal consciência, e incapaz de diagnosticar com precisão o elemento a ser combatido, a rebeldia não encontra aqui um sistema estruturado de forma usual contra o qual se rebelar. Urge então compreender os processos envolvidos na constituição e reprodução desse império como hegemon ${ }^{30}$.

Indubitavelmente, a velocidade das mudanças tecnológicas na contemporaneidade, que permitiu a aceleração dos processos de criação de um sistema-mundo efetivamente conectado e turboglobalizado ${ }^{31}$, não alterou apenas as relações econômicas entre os Estados, cuja distância, relativizada por melhores meios de transporte e instrumentos de comunicação, não seria mais único fator decisivo. De fato, a turboglobalização contemporânea é um dos principais desdobramentos de uma sociedade hiperpositiva; ela é efetivamente uma manifestação da própria "ideia única"; o império da ideia única estabelece e mesmo fomenta ativamente essa turboglobalização como o mecanismo de viralização do "terror do igual":

29 "As imagens hostis produzidas pela imaginação ajudam o si mesmo a formar uma 'figura' objetivável que o liberta da relação narcisista paralisante e que o resgata de seu mergulho no vazio subjetivo." (HAN, 2017a, p. 102)

30 Significativamente, tomamos o termo à teoria da estabilidade hegemônica, inaugurada pelo americano Charles Kindleberger e que propõe justamente que uma economia liberal só pode ser mantida no mundo por meio da dominação do cenário internacional por uma potência hegemônica capaz de assegurar tal sistema (KINDLEBERGER, 1981, p. 242-254; 1986)

31 Tomamos o termo de empréstimo ao filósofo catalão Gonçal Mayos, o qual mostra que diferentes modelos de globalização ao longo da história culminaram, na modernidade, não apenas na aceleração exponencial dos processos de conexão e dos fluxos de trocas desse tempo, mas inclusive no intenso crescimento da sua quantidade e qualidade. (MAYOS SOLSONA, 2018; 2019). Han também se aproxima de uma percepção semelhante sobre a aceleração (elevação de entropia) de nosso tempo: "A atual crise temporal não se chama aceleração; em si a aceleração não é destrutiva. Temporariamente, um crescimento acelerado de células pode fazer muito sentido na medida em que se submeta à economia de todo o organismo. Onde a aceleração se projeta para além de toda e qualquer determinação de sentido, alcançando autonomia, adquire uma forma diabólica. [...] A aceleração autêntica pressupõe um processo que se dirige a uma meta. O que hoje se percebe e compreende por aceleração é, na realidade, uma veloz elevação da entropia, que faz as coisas entrarem em um torvelinho de agitação e proliferação, gerando, assim, uma massa de saturação e sufocação." (HAN, 2017a, p. 197) 
A globalização força a deposição do umbral imunológico, uma vez que uma forte reação imunológica diante do outro poderia bloquear esse processo de globalização, que é um excesso de desbloqueio e de supressão de barreiras. Nesse sentido, a violência da positividade se desenvolve no espaço livre de negatividades do igual. A falta de negatividade faz surgir uma proliferação descontrolada do positivo, que, em virtude de sua imanência, não se depara com qualquer tipo de resistência imunológica. Ela é um terror do igual (HAN, 20I7a, p. I54-I55).

Assim, o império da ideia única se desdobra em todos os âmbitos da vida, com maior ou menor intensidade, influenciando e reestruturando ou desestruturando os mais diferentes aspectos dela. O próprio relacionar-se do sujeito foi modificado, a lógica da negatividade construída ao longo da história, a qual constituiu o desenho institucional e político da modernidade, perdeu seu lugar de destaque para a positividade. O sujeito inserido na "sociedade de desempenho" é reformatado internamente por sua própria vontade, ele se constitui psiquicamente não mais pelo dever algo, mas sim pelo poder tudo; isto é, a disciplina como forma de coerção transmuta-se em excesso de liberdade, esta serve de disfarce para o controle político e social dos cidadãos.

Uma das manifestações mais funestas desse império, entretanto, e aquela que mais diretamente nos interessa aqui, é a desestabilização com vistas mesmo à desintegração do Espírito Objetivo. Este, talvez a mais importante descoberta filosófica da história ou, no mínimo, da modernidade, se desenvolve na percepção propriamente hegeliana do "eu que é um nós, e do nós que é um eu", isto é, de que para além das subjetividades existe uma objetividade que é Espírito, ou seja, que pode ela também ser compreendida como uma consciência para além da consciência do homem particular, de modo a suprassumir a simples forma do Espírito Subjetivo ensimesmado, agora como ideia, e exteriorizar a consciência de que é livre.

Quando o espírito superou sua falha [...]; quando, portanto, seu conteúdo não está mais em discrepância com sua forma; [quando] a certeza da razão, a unidade do subjetivo e do objetivo, não é mais formal, mas antes preenchida; quando, pois, a ideia forma o único conteúdo do espírito - então o espírito subjetivo atinge sua meta e passa a [ser] o espírito objetivo. Este sabe sua liberdade, conhece que sua subjetividade constitui, em sua verdade, a própria objetividade absoluta, e não se apreende simplesmente em si mesmo como ideia, mas se produz como um mundo, exteriormente presente, da liberdade (HEGEL, I995, p. 219).

O Espírito Objetivo se apresenta, ele também, como um outro a partir do qual a identidade pode se formar, isto é, se coloca como negatividade para a consciência subjetiva que participa dele, mas dele se percebe distinta. "O espírito, que significa originalmente estímulo ou ser-atingido, jamais é totalmente transparente” (HAN, 20I7a, 
p. 203). Assim, a formação de toda identidade carece, dialeticamente, de negatividade para se tornar consciente de si mesma. Nesse sentido, a violência, seja ela real ou simbólica, como negatividade, é essencial à identidade. A violência positiva, traço distintivo de uma sociedade hiper-hipócrita, fruto do império da ideia única, que esconde a violência que exerce nos recônditos da própria mente moldada para as lógicas do individualismo e do desempenho, mascarada como pura positividade, não constitui identidade. Deixa, portanto, os sujeitos soçobrarem em uma existência vazia de sentido. Não há rebeldia no inferno do igual!

O sujeito da obediência e o sujeito disciplinar se encontram com o outro, que se manifesta como Deus, soberano ou consciência moral. Estão submetidos a uma instância exterior, da qual provêm não apenas repressão e punição, mas também gratificação. O sujeito da sociedade de desempenho, ao contrário, é marcado por uma autorrelacionalidade narcisista. Em virtude da falta de gratificação por parte do outro, ele se vê obrigado a produzir sempre mais e cada vez com melhor desempenho. Também a negatividade do outro, onde ainda habita a relação de concorrência, é um elemento que falta ao sujeito de desempenho, pois, em última instância, ele está concorrendo consigo e procura se superar. Isso acaba desembocando em uma corrida competitiva fatal e também em um círculo infinito em torno de si mesmo, que, em algum momento, acabará ruindo (HAN, 20I7a, p. IOO-IOI).

A negatividade é fator axial da sociedade, mormente desde a modernidade. Ela é elemento central na concepção contemporânea de política, inclusive na perspectiva extrema desenvolvida por Carl Schmitt. Este propõe o conceito a partir de contradições - negatividade expressa - típicas das relações de poder. $\mathrm{O}$ critério conceitual marcante em sua perspectiva sobre a política é a diferenciação entre amigo e inimigo ${ }^{32}$. O inimigo schmittiano, sem dúvidas, exerce precisamente esse papel de instância de negatividade, o outro a partir do qual a identidade (subjetiva ou nacional, por exemplo) se forma:

Ele [o inimigo político] é, precisamente, o outro, o estrangeiro, e é suficiente, para a sua essência, que ele seja existencialmente, num sentido particularmente intensivo, algo outro e estrangeiro, de tal modo que, em caso extremo, sejam possíveis conflitos com ele que não possam ser decididos nem por uma normatização geral, que possa ser encontrada previamente, nem pela sentença de um terceiro "não participante" e, portanto, "apartidário" (SCHMITT, 2020, p.52).

Nesse sentido, talvez a tese da amistosidade/amabilidade de Han se revigore e se torne mais compreensível como uma busca por reconstituir o espaço

32 Para uma revigoração bastante mais criativa da e para além da perspectiva schmittiana, cf. Mouffe (2015). 
do político, escapando da prisão da mera existência33. Para tanto, se vale da perspectiva aristotélica: "Aristóteles radica a amizade em um nível bastante fundamental, em um nível existencial. Assim, o Estado coloca a amizade como seu fundamento, como a condição de possibilidade de sua existência na medida em que nada mais representa além da 'livre decisão para a convivência”" (HAN, 20I7a, p. 124)34.

A perspectiva da amabilidade pretende avançar para além do paradigma moderno da tolerância, segundo o qual o outro é deixado a si, para um paradigma de compreensão do outro, que envolve uma tomada de posição ativa em face dele, não no sentido de anulá-lo na chave schmittiana do inimigo, mas como a construção de um ambiente onde ambos possam exercer suas liberdades autonomamente e interagindo entre si. Para isso, contudo, a conformação de um Espírito Objetivo, de uma instância de poder interpessoal que estabeleça esse espaço de convívio, se faz necessária. E é justamente esta a instância sob maior ataque na contemporaneidade. "Precisamente, o que caracteriza a sociedade atual é que esse sentimento de pertencimento, o nós, começa a desaparecer por toda parte. A apatia e a indiferença política, ao lado da infantilização crescente da sociedade, tornam bastante improvável uma ação conjunta" (HAN, 20I7a, p. 243-244).

Para compreender esse ataque, entretanto, é importante compreendermos brevemente o Zeitgeist, o espírito-do-tempo que norteia a ação e os traços característicos desse império tão distinto de seus antecessores: o "império estadunidense". Sem dúvida, a incapacidade de compreender e, assim, aceitar ou tolerar a política está no cerne desse império. Assim, é significativa a crítica quase velada que Han faz ao estilo de vida do coração do império, os Estados Unidos da América ${ }^{35}$ :

As organizações que têm um cunho puramente econômico e que se orientam apenas na obtenção de lucro não poderão formar comunidade. A razão disso é que lhes falta a dimensão da política. O sistema econômico cujo código binário seja "lucro/prejuízo" não tem olhos para ver o bem-estar comum. Precisamente aqui é que se mostra a verdadeira essência do político (HAN, 20I7a, p. I24-I25, nota).

\footnotetext{
33 Talvez, afinal, o existencialismo não tenha sido uma forma de politicídio mais ou menos consciente, como busca demonstrar Middelaar (2015), mas seja também ele uma manifestação trágica do espíritodo-tempo em um momento de consolidação do império do pensamento único lastreado na visão de mundo pobre de cultura e praticamente desprovido de "politicidade" do império estadunidense. Nesse sentido, poderia ser justamente em meio à busca por um sentido fundamental para o humano, num momento de medo, insegurança e individualismo de que é prenhe o século XX, que o existencialismo se arremessa à prisão da mera existência. No horizonte de vedação à política, o fundamento de humanidade se constituiu então quase em animalidade. Isto é, não sendo zoónpolitikon, resta apenas o zoón.

O texto citado é Política (ARISTÓTELES, 1998).

35 Obviamente não se trata de uma crítica direta aos EUA. Entretanto, para qualquer observador atento, as semelhanças entre aquela organização institucional e uma empresa de facto, bem como a feroz defesa que aquele país faz das suas corporações, transbordam a crítica de Han, atingindo em cheio a sociedade estadunidense.
} 


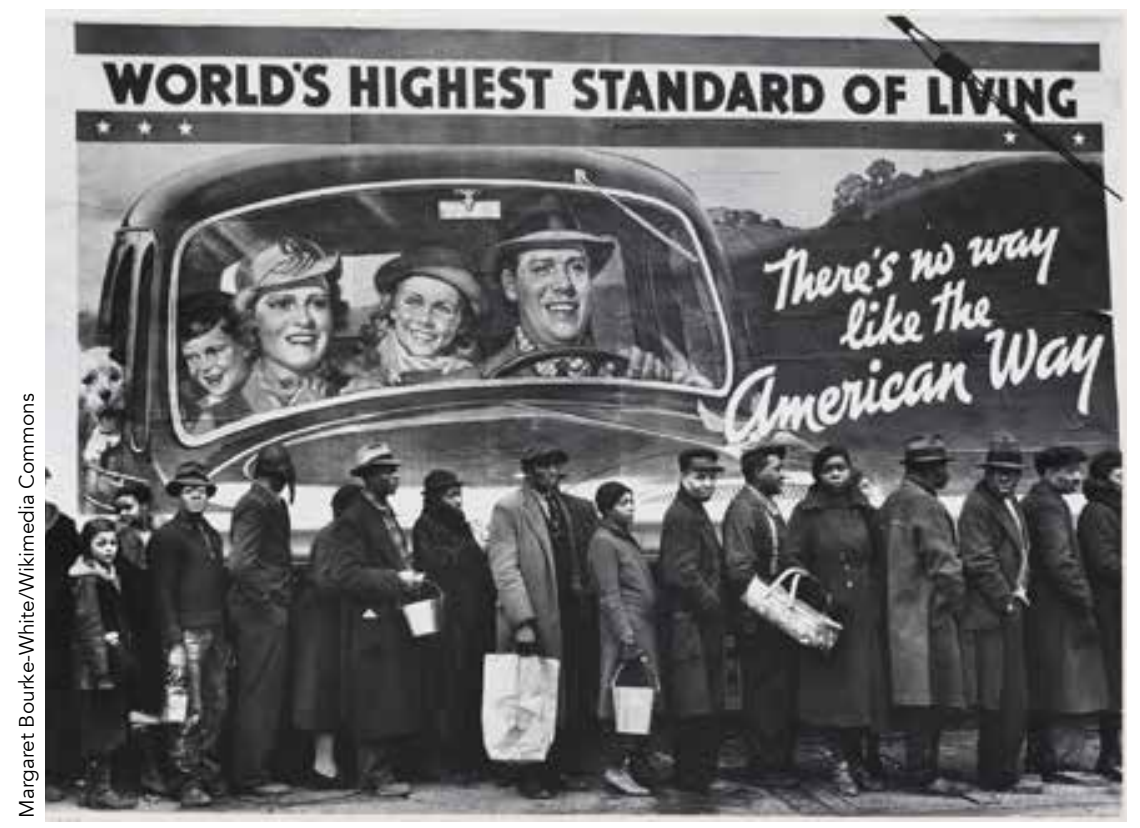

"O melhor padrão de vida do mundo. Não há jeito melhor que o estadunidense", diz o cartaz, que retrata uma típica família branca dos EUA. Em frente a ele, fila de pessoas diante de um posto de distribuição de sopa para desempregados, durante a crise de 1929 no país

A política, por outro lado, em tudo se distingue tanto da lógica empresarial do gerenciamento de lucros e prejuízos quanto da pretensão imperial do domínio puro e simples: "Em sentido próprio, política não é a vontade de exercer o domínio, mas a decisão de viver conjuntamente. A vida humana não se politiza ao se abandonar incondicionalmente ao poder; somente a decisão de viver juntos é que politiza a existência humana" (HAN, 20I7a, p. I24-I25). Se, por um lado, uma empresa não existe em função da política e não tem qualquer preocupação com o bem-estar comum de seus acionistas, a lógica que instrui o Espírito Objetivo, enquanto momento de suprassunção das subjetividades em uma totalidade livre e libertadora, é em tudo oposta àquela. Mormente no seu momento de cumeada do caminhar da eticidade do Espírito Objetivo, isto é, no momento do Estado - e, sobretudo no Estado de direito com suas características distintivas - , quando a politicidade se encastela como centro norteador da ação coletiva com vista a fins (a teleologia do Estado) ${ }^{36}$.

É, portanto, o Espírito Objetivo em geral, e o Estado, em particular, que constituem os alvos preferenciais contra os quais investe a violência hiperpositiva do império da ideia única. Nesse sentido, é também notável perceber o ataque sofrido por uma outra instância do Espírito Objetivo, a religião, na contemporaneidade:

A religião [...] é um sistema de negatividade. Com seus mandamentos, proibições e rituais ela se contrapõe à proliferação do positivo. Ela faz surgir sinais e espaços claramente delimitados, carregados de tensão altamente semântica e atmosférica. Desse modo mantém a entropia do sistema social em um nível

36 Toda teleologia, toda proposta de um Destino, subjetivo ou de Estado, estão também dificultadas pela violência positiva: "A vida desnudada faz desaparecer toda e qualquer teleologia, todo e qualquer 'para que', em função dos quais o ser humano deveria ser sadio" (HAN, 2017a, p. 49). Uma busca recente de uma retomada da teleologia do Estado brasileiro foi defendida em sede de sua tese de cátedra por Horta (2020). 
bastante baixo. A orgia da libertação, a desregulamentação, a supressão de limites e a desritualização, que prosseguem até os dias de hoje, vão demolindo cada vez mais a negatividade. Essa destruição da negatividade gera excesso de positividade, grande promiscuidade e excesso de mobilidade, consumo, comunicação, informação e produção (HAN, 2017a, p. I85).

Assim também a política da positividade será marcada pelo excesso de demandas, pela multiplicação de exigências prementes e urgentes, pelo esvaziamento de todo sentido de totalidade. A positividade mantém a entropia do sistema social permanentemente alta como forma de constante desestabilização de qualquer instância de poder objetivo que se queira estabelecer como proposta de sociabilidade efetiva ${ }^{37}$. A massificação da comunicação das demandas políticas ${ }^{38}$, dos processos, do consumo gera a elevação exponencial da entropia de todos os sistemas sociais, que se tornam incapazes de lidar de forma útil com essa onda de informações. "A partir de um determinado ponto a informação não é mais informativa, a produção já não é produtiva, a comunicação não é mais comunicativa. Tudo cresce e prolifera para além de sua meta, para além de sua determinação, para além da economia da utilidade" (HAN, 2OI7a, p. I86) ${ }^{39}$. Em tal contexto, não é surpreendente o temor de que qualquer momento do Espírito Objetivo que seja capaz de se organizar de forma consciente de si seja desde logo encarado como uma ameaça ao império vigente.

Assim, a supressão da negatividade, o excesso de transparência e a ilusão de liberdade vão afetando a tudo, tanto ao sujeito quanto ao coletivo político, isto é, ao próprio Estado. Neste, o controle interno autoviolento é exercido por um gerencialismo pseudopolítico e se dá pelas fórmulas neoliberais aclamadas como soluções econômicas de sucesso para as crises financeiras especulativas, frequentemente proporcionadas pelos mesmos detentores das soluções; nesse caso o lucro disfarçou-se com as vestes da liberdade ${ }^{40}$.

\footnotetext{
37 "A comunicação do global é uma comunicação pós-imunológica. É precisamente pela falta de negatividade imunológica que se chega a uma supercomunicação. E a massa comunicativa que surge com isso acaba propiciando uma crescente entropia do sistema." (HAN, 2017a, p. 196-197)

38 Uma das primeiras constatações da massificação de tudo na contemporaneidade pode ser encontrada no grito desesperado de Ortega y Gasset: "As cidades estão lotadas de gente." (ORTEGA Y GASSET, 2016, p. 78) Notavelmente, essa constatação consternada se encontra em capítulo intitulado precisamente "O fato das aglomerações"

39 A hipercomunicação e o excesso de informação nesse caso deixam de ser apenas formas de violência positiva sem atores facilmente identificáveis para se mostrarem uma necessidade impositiva de um mundo do absurdo e do sem sentido. Parar para refletir talvez desativasse o torpor da hiperviolência deste "capitalismo de desastre" (KLEIN, 2008), e justamente por isso a reflexão é combatida pela ideia única. A hipercomunicação anestesia a sociedade do espetáculo para o fato de não estar diante de um picadeiro, mas perante o mundo real de absurdos inomináveis e violências inaceitáveis. A violência positiva, nesse sentido, deve ser compreendida como um projeto

40 Exemplo significativo desse tipo de pseudopolítica é a praxe de implementar no direito interno (des) regulações trabalhistas recomendadas e publicadas desde 2004 pelo Banco Mundial, através de um informativo nomeado Doing business (relatórios subnacionais de Doing business capturam diferenças nas regulamentações de negócios e sua imposição entre locais em um único país; eles fornecem dados sobre a facilidade de fazer negócios, classificam cada local e recomendam reformas para melhorar o desempenho em cada uma das áreas analisadas), responsável por comparar e sugerir os ordenamentos jurídicos mais eficazes na ótica do mercado, levando em conta, inclusive, a rigidez do direito trabalhista. Nesses cenários mostra-se um exemplo do falseamento enganoso de que as imposições do império do pensamento único são as formas mais efetivas para o ganho econômico.
} 
Como tal, a política é uma ação estratégica; é constitutivo dela uma esfera secreta. Essa esfera distingue-se de uma mera regência e administração, que não passaria de trabalho. A ação política não é trabalho. A publicação de todas as intenções também impossibilita o jogo, pois este também é um fazer estratégico. Onde não é possível traçar uma estratégia existe apenas estatística, como sondagens de opinião (HAN, 2017a, p. 206-207).

Para além do direito e da política, a própria cultura pertencente ao povo de um Estado, a manifestação mais espontânea do Espírito Objetivo, se vê igualmente sob ataque do império do idêntico. Nesse sentido, elementos exógenos são impostos aos cidadãos despidos de sua cidadania, compreendidos apenas como consumidores, totalmente planificados na estrutura lisa do consumo. Um único produto deve ser consumível por sujeitos em qualquer lugar do mundo, pertencentes a qualquer civilização do globo, para maximizar os lucros reduzindo drasticamente os custos de se adequar a realidades e demandas locais. Assim, leiloa-se a epítome do direito internacional moderno, o direito à autodeterminação dos povos, para maximização dos ganhos ${ }^{4 \mathrm{I}}$.

A coação por transparência, em última instância, não é um imperativo ético ou político, mas econômico. Iluminação é exploração; comunicação é comércio. Quem está totalmente exposto à iluminação está inapelavelmente entregue à exploração; a superiluminação de uma pessoa maximiza a eficiência econômica. O cliente transparente é o novo interno, o homo sacer do panóptico econômico (HAN, 2OI7a, p. 2II).

Também a política e a religião interditadas são reapropriadas por esse império do capital como forma de entregar aos sujeitos-consumidores um arremedo de sentimento de pertencimento, uma verdadeira troça ao Espírito Objetivo mesmo, por sua transmutação em mera mercadoria. O entretenimento é propaganda, a arte é produto, a política é espetáculo, a religião é o capitalismo.

Já faz muito tempo que o domínio e o esplendor abandonaram o campo político, deslocando-se para o campo do capital. As propagandas representam a versão capitalista dos hinos e cânticos litúrgicos. Estrelas que elogiam os

\footnotetext{
Contra esse movimento, diversos pensadores têm se dedicado a pensar formas de resistência a essa invasão não mediada de elementos culturais exógenos; em especial, a perspectiva da "diatética cultural", como defesa cultural, vem sendo desenvolvida na Faculdade de Direito da Universidade Federal de Minas Gerais: "Sob a alegação da existência de autênticas civilizações, ou centros de poder cultural, informacional, intelectual ou artístico, as nações acabam por diluir em seu espaço popular elementos estrangeiros, alheios à realidade local e às experiências, mas que se comunicam com as vivências dos cidadãos e transmitem valores. Estes são sustentados em interesses de intercâmbio cultural globalizante sob uma primeira interpretação, ingênua, mas que podem, estrategicamente, carregar valores de fragmentação da unidade cultural doméstica, degradando as experiências culturais em prol de uma realidade artificial e estranha, nutrida, em segundo plano, por interesses de dominação cultural que são, no mínimo, interessantes do ponto de vista mercadológico, mas que demonstram o seu verdadeiro poder no seu potencial geopolítico de aplicação. $\bigcirc$ choque de civilizações ocorre com o deslocamento do front de combate potencial das nações para a cultura. É, antes, um embate de matrizes culturais do que propriamente uma ameaça bélica. A ameaça é virtual e tal natureza pode subestimar as armas aplicadas em nível geopolítico que ferem a unidade e harmonia dos povos." (CARDOSO, 2016, p. 102)
} 
novos produtos são os anjos de hoje; os hinos de louvor capitalistas geram o esplendor e a glória. É o belo esplendor do domínio, aplicado e válido exclusivamente ao capital. A aclamação que se oferece ao domínio do capital se chama, agora, consumo (HAN, 20I7a, p. I34-I35).

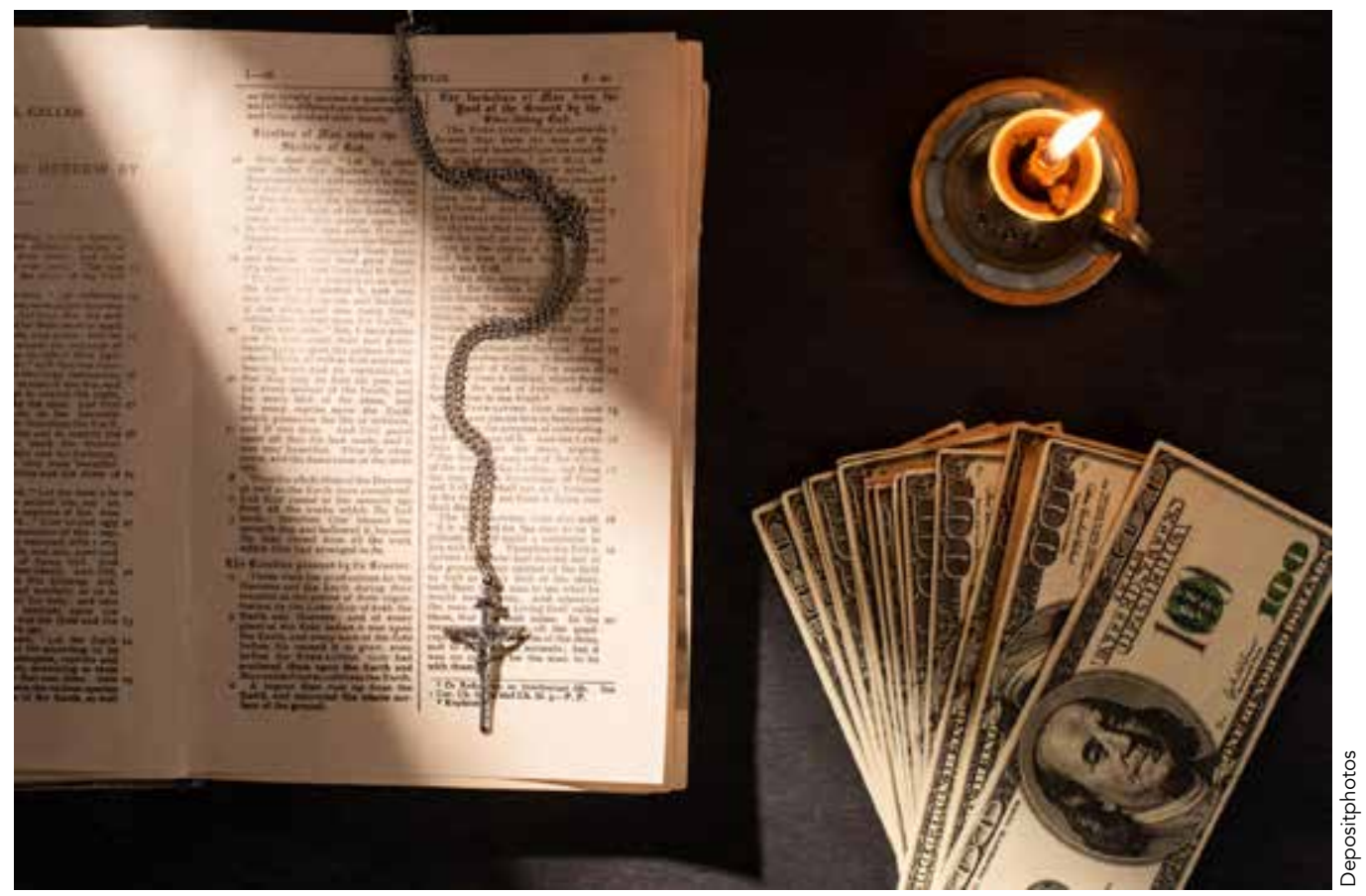

Assim desintegrado o Espírito Objetivo, ou ao menos fortemente atacado, encontra-se em um momento de máxima fragilidade, que leva mesmo Han a duvidar de sua capacidade de responder aos desafios pela frente. "A falta de contrapoder perpetua a ordem econômica neoliberal, a qual, por sua vez, desenvolve uma forte energia de apropriação que absorve tudo, transformando-o em moeda de troca da fórmula capitalista" (HAN, 20I7a, p. 245). Ainda assim, não há que se questionar que o Estado soberano, tomando seus destinos nas próprias mãos, ainda possui a capacidade única de se contrapor em alguma medida e de forma relativamente eficaz a esse paradigma imperial. Justamente aqueles assim chamados rogue States pela própria diplomacia estadunidense são Estados que se colocam mundialmente contra essa imposição uniformizadora, ainda que arcando com as pesadas consequências de se indispor contra o império vigente.

Logo, apesar de uma certa descrença de Han nesse caminho de um "romantismo pós-moderno das singularidades" (HAN, 20I7a, p. 195), é preciso considerar que o atual estado de intenso achincalhamento de todas as instâncias do Espírito Objetivo, somado à permanente busca dos sujeitos por formas de reconexão - que, ante o ataque ao Estado, à cultura nacional, à religião, entre outros, toma por expressão mais corrente e corriqueira o acesso a um misticismo pré-fabricado e de mero consumo - indica o 
caminho para a recuperação da liberdade do Estado para se colocar em rebeldia no plano mundial, naquele verdadeiro "estado de bravura" que aqui buscamos recuperar.

\section{LEVIATÃ PORTADOR DO FOGO DIVINO}

Lembrai-vos, ao menos, do que vos preveni!... Se a calamidade que se aproxima vos atingir, não acuseis a sorte... nem digais que Júpiter vos feriu com imprevistos golpes de violência. De vós, tão-somente, será a culpa... Fostes em tempo avisadas!

Não será, pois, por falta de luzes, ou de tempo, que sereis imprudentemente arrastadas pela rede das desgraças

Sófocles, "Prometeu acorrentado"

Diante de um inimigo que recua às instâncias subcutâneas, subcomunicativas e mesmo capilares para não se apresentar como tal, urge, antes de mais nada, no esforço por possibilitar uma rebeldia contra um status quo que adquiriu mesmo um caráter "dóxico" 42 , justamente realizar aquilo que, até aqui, buscamos empreender, isto é, urge narrar esse inimigo. Mas como caracterizar o império do pensamento único é uma questão que ainda não pôde ser bem esclarecida. Saber de onde e de que forma se exerce tal domínio é essencial para que possamos justamente reagir conscientemente ao seu domínio global crescente. É esse indubitavelmente o caminho para nos evadirmos da acertada crítica de Han: "A guerra se estende e vai adentrando, inclusive, a alma de cada um. Travamos guerra não apenas com o outro, mas sobretudo conosco. Mediante essa totalidade e imanência da guerra, aquela resistência clássica que pressupunha separação nítida entre interior e exterior [...] não tem força e atuação" (HAN, 20I7a, p. 25I). Contra um inimigo que se virtualiza em pura positividade, e que se confunde mesmo com a liberdade individual, somente o chamado à luz inequívoco de sua ação pode talvez tentar gerar a consciência da necessidade e principalmente das possibilidades de formas de enfrentamento. A nosso favor socorre o fato de que, se ainda é necessário ao império lançar mão da violência (mesmo que positiva) para a imposição de seu domínio, é porque ele ainda não é plenamente aceito como inevitabilidade tout court.

A resistência massiva contra o detentor do poder atesta a falta dele; justamente por carecer de poder apela para a violência. A utilização da violência seria a tentativa desesperada de converter a impotência em poder. O detentor de poder que realmente é poderoso não deve essa capacidade à violência. Fazendo uso dela pode-se forçar o poder, mas nesse caso ele é frágil; irrompe facilmente, quiçá em virtude da fissura provocada pela violência. É um erro supor que o poder resida na violência, pois ela tem uma intencionalidade oposta (HAN, 2OI7a, p.I46).

42 O termo refere-se à noção platônica de doxa, como opinião não refletida, ou senso comum (PLATÃO, 2012, em especial o livro V). 
Assim, se, por um lado, é contra o Espírito Objetivo e contra o Estado, especificamente, que investe o império da ideia única, resta necessária a intuição de que seja também ali, naquele espaço que em tudo se contrapõe ao referido império, que restem ocultas as chaves para o exercício da rebeldia capaz de debelá-lo, e significativas pistas podem, sem dúvida, ser encontradas a respeito do caminho a percorrer. Significativamente, é preciso compreender que o império age na lógica da simples decisão, e contra isso é precisamente o resgate da politicidade que se coloca como horizonte de resoluta rebeldia e de possibilidade de reconstituição de um Espírito Objetivo verdadeiramente capaz de dar vazão às justas expectativas, tipicamente ocidentais, relativas ao exercício democrático do poder em um Estado de direito autêntico e autodeterminado: "A decisão é uma tomada de decisão sem intermediação, através da espada; ela se apoia na violência. Já a discussão como o medium do político segue um espírito completamente diferente; em lugar do combattere entra o compromettere." (HAN, 20I7a, p. 93) $)^{43}$

Hoje, a própria política positiva-se num trabalho, sem qualquer chance de um agir soberano. O trabalho é positivo na medida em que ele jamais consegue se colocar em questão e se elevar para além das forças e coações às quais está submisso. A positividade do trabalho perpetua o estado de normalidade. Falta à política, enquanto trabalho, qualquer horizonte transcendental que remeta para além do meramente possível. A política se aconchega tranquilamente no espaço imanente do capital, que, nesse ínterim, absorve toda e qualquer transcendência, todo e qualquer exterior. Diante da positivação da política, também os partidos políticos ou as ideologias estão perdendo cada vez mais sua importância. O vazio político é preenchido com espetáculos de encenações midiáticas. Também os políticos se voltam e se inserem no espaço despolitizado do espetáculo. Não é sua ação política, mas sua pessoa que se torna objeto de encenação midiática (HAN, 20I7a, p. I32-I33).

Uma necessária constatação nesse sentido, entretanto, é a de que assim como o sujeito de desempenho exerce sobre si mesmo uma violência autorreferente ${ }^{44}$, também o "Estado democrático de desempenho" - e que expressão sumamente antitética tem exercido sobre si uma enorme violência pautada por um desempenho (especialmente econômico) que o torna vítima de si mesmo. Essa violência autoimposta é espe-

43 Também é significativa nesse ponto a crítica de Han à leitura de Walter Benjamin sobre a política parlamentar em sentido similar: "Benjamin claramente não compreende a essência do parlamento. Trata-se de um lugar para falar uns com os outros (parler). O parlamento desloca a imposição do direito da violência para o discurso; os acordos são livres da violência na medida em que permanece a discussão mútua. Na violência, ao contrário, habita a mudez absoluta, a perda da fala. [...] Quem realmente possui a mentalidade da violência não se permite fazer acordos. Já a democracia tem um núcleo essencial comunicativo; ao falarem, as minorias também podem influenciar um processo de decisão. A ditadura proíbe o falar; ela dita." (HAN, 2017a, p. 108-109)

44 "O que perfaz sua constituição psíquica [a do sujeito de desempenho] não é o dever, mas o poder. Ele tem de ser senhor de si; não são ordens ou proibições, mas liberdade e iniciativa que determinam sua existência. $\bigcirc$ imperativo do desempenho converte a liberdade em coação; em lugar da exploração estranha entra autoexploração, sendo que o sujeito de desempenho explora a si mesmo até se ruir. Aqui, a violência torna-se autorreferente; aquele que explora é explorado; o agressor é, ao mesmo tempo, a vítima." (HAN, 2017a, p.182) 

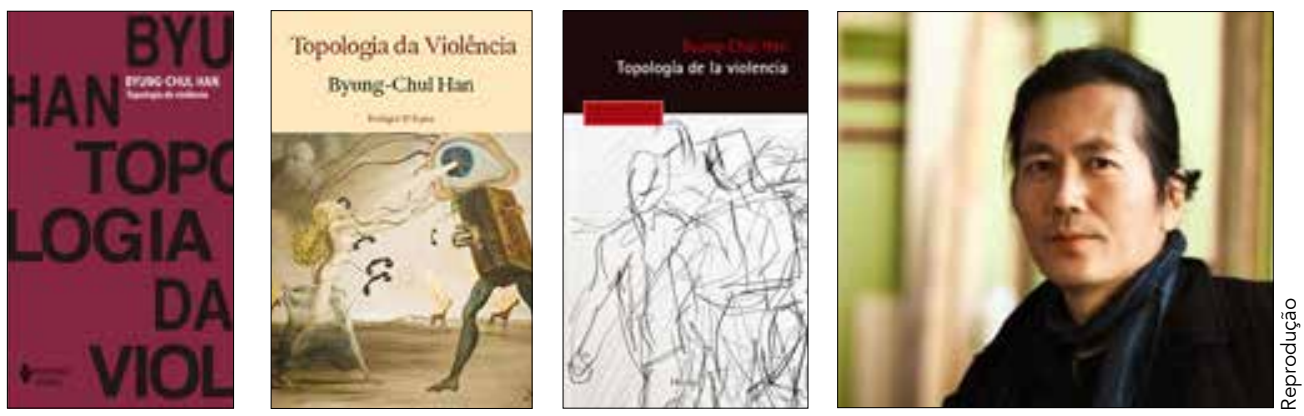

Edições em português e espanhol do livro Topologia da violência, do filósofo sul-coreano Byung-Chul Han

cialmente perniciosa entre os Estados mais marginalizados - eis aí, aliás, uma grande diferença entre o império e o Estado de direito, pois este, idealmente, se ocupa a todo tempo de minorar as marginalidades que seu próprio poder incessantemente provoca.

Os países mais pobres tentaram se levantar, copiando as instituições dos países mais ricos e abrindo-se para uma economia mundial comandada justamente por essas nações mais opulentas. Os países mais pobres acreditavam que bom comportamento seria recompensado com rápido ponto de convergência, marcado com um encontro primeiramente com as práticas dos mais adiantados e posteriormente com a prosperidade desses últimos mais ricos (UNGER, 2005, p. 15).

Justamente por essa razão, é preciso que a rebeldia de Estado se exerça também contra esse imperativo da ortodoxia econômica que não pode, contudo, se fiar em alquimias - é preciso um pensar rigoroso, sério, e principalmente democrático, dos caminhos a se trilhar. De essencial primazia, nesse sentido, é a urgência de desconectar certas conexões pouco lógicas entre termos completamente díspares entre si:

Entre os grandes inimigos espirituais do impulso experimentalista na recriação de instituições está a superstição do fetichismo institucional que tudo permeia: a identificação inibidora e injustificada de concepções institucionais abstratas, como a democracia representativa e a economia de mercado, com um conjunto específico e contingente de estruturas institucionais (UNGER, 2004, p. I8).

Outro elemento de rebeldia sempre à disposição é a apropriação criativa das tentativas e erros de outros Estados: "Os países mais bem-sucedidos, tanto em desenvolvimento econômico como em autoafirmação, foram com frequência os mais persistentes pilhadores de práticas e estruturas de todo o mundo" (UNGER, 2004, p. I7 $)^{45}$. Em favor dessa mesma rebeldia se coloca justamente a lógica inerente ao próprio poder, que é em si mesma uma lógica construtiva e imediatamente oposta ao domínio 


\section{Não é mera coincidência que justamente} as grandes narrativas dos povos estejam sob ataque (por vezes, inclusive por parte de bem-intencionados pensadores que, na busca por valorizar narrativas parciais, descuram de reintegrar suas perspectivas nos horizontes mais largos de uma grande narrativa, em sentido inclusive épico)

e ao império. Não é mera coincidência que alguns, ou mesmo a maioria, dos arautos imperiais se apressem a decretar o fim da soberania estatal. A soberania já é, por si só, um forte exercício anti-imperial.

Um poder absolutamente destrutivo é uma contradição, pois seu núcleo sempre é construtivo. $O$ poder trabalha, organiza e elabora para si um espaço de atuação na medida em que produz normas, estruturas e instituições; na medida em que se inscreve em uma ordem simbólica. [...] Nietzsche reconheceu muito bem a intencionalidade específica do poder, que o distingue da violência: "O sentimento de poder é conquistador, depois dominante (organizador) - regula o que foi suplantado para sua conservação, e para isso preserva aquilo mesmo que foi suplantado." (HAN, 20I7a, p. I45)

Esse caráter construtivo do poder indubitavelmente se relaciona com o ataque que todo poder particular, não adstrito ao império do pensée unique, especialmente o poder dos Estados, vem sofrendo, bem como com a forma desse ataque. Nesse sentido, não é mera coincidência que justamente as grandes narrativas dos povos estejam sob ataque (por vezes, inclusive por parte de bem-intencionados pensadores que, na busca por valorizar narrativas parciais, descuram de reintegrar suas perspectivas nos horizontes mais largos de uma grande narrativa, em sentido inclusive épico). Afinal, desnudar o poder de suas narrativas, de suas utopias, na prática, é uma das mais eficazes ferramentas para sua destruição: "Espaços de poder também são espaços de linguagem. Assim, estão plenos de símbolos, sinais e significados. Quem quiser destruir um espaço de poder, um corpo de poder, tem de desnudá-lo e privá-lo especialmente de sua linguagem" (HAN, 20I7a, p. I49).

Urge, portanto, a rebeldia de encontrar soluções criativas que sejam capazes de se contrapor a esse processo, retomando as possibilidades de ação conjunta que, como bem percebe Han, vão se diluindo em um crescendo: "A sociedade atual está em processo de diluição: do social, do comum e do comunitário. Ela está se atomizando e se particulari- 
zando a olhos vistos" (HAN, 20I7a, p. 248). Se podemos e talvez devamos concordar com o diagnóstico do filósofo teuto-coreano, ainda resistimos a acatar plenamente sua tese para a solução da questão. Da parte dele, o argumento é de que ainda nos aferramos, como Baudrillard, a um "romantismo das particularidades" que insiste em acreditar na capacidade de renovação das antigas estruturas do Espírito Objetivo. De nossa parte, o argumento é de que talvez a tese da amabilidade ainda se encontre muito atrelada ao paradigma da individualidade, que, cremos, pode ser igualmente superado, dado que é ele próprio uma manifestação da cultura imperial externamente imposta. Certo, entretanto, é que a mútua desconfiança não redunda em uma incompatibilidade essencial entre as duas teses: o nosso Estado de direito e a amabilidade não são irreconciliáveis. Aliás, uma manifestação da amabilidade, a fraternidade, se inscreve mesmo no lema da Revolução Francesa que fez efetivar no mundo este nosso novo modelo de Estado.

De fato, talvez Han tenha alguma razão ao supor que a solução possa passar também por uma libertação do sujeito de desempenho para o ócio e a criatividade, isto é, para o chamado nietzscheano ao homem soberano, que é seu ponto antipodal:

O homem soberano de Nietzsche é, na verdade, um contramodelo crítico cultural do sujeito de desempenho esgotado, depressivo. Assim, ele figura como um homem do ócio. Para Nietzsche, a contramão desse direcionamento seria o hiperativo. A "alma forte" conserva propriamente a "calma", "move-se lentamente" e sente "aversão contra o que é por demais vivaz". Em Assim falava Zaratustra, Nietzsche escreve: "a todos que amam o trabalho bruto, e amam a celeridade, a novidade, o estranho — vós vos portais mal, vossa operosidade é fuga e vontade de esquecer a vós mesmos. Se acreditásseis mais na vida, vós vos lançaríeis menos ao momento. Mas para a espera não tendes suficiente conteúdo em vós - e inclusive não a tendes para o ócio ${ }^{46}$ (HAN, 20I7a, p. 266-267).

$46 \bigcirc$ trecho de Nietzsche que Han cita se encontra no instigante sermão "dos pregadores da morte", onde se lê: "Há pregadores da morte, e a terra está cheia daqueles para os quais é preciso pregar a desistência da vida. Cheia está a terra de supérfluos, corrompida está a vida por muitos dentre os muitos. Que saiam dessa vida, atraídos pela 'vida eterna'! [...]. Essas criaturas terríveis sequer se tornaram homens. Que preguem a desistência da vida e desapareçam! Há os espiritualmente depauperados: logo que nascem começam a morrer e anseiam por doutrinas de lassidão e renúncia. Desejariam eles estar mortos, e deveríamos aprovar o seu desejo! Vamos nos guardar de despertar esses mortos e de lhes violar os caixões da vida. Quando se reúnem com um velho, um inválido ou um cadáver, — dizem logo: 'a vida é refutada'. Eles é que são refutados; e os olhos deles só veem um aspecto da existência. Envoltos em densa melancolia e ansiosos [por] que pequenas coincidências Ihes tragam a morte: é assim que esperam com os dentes cerrados. Ou então tentam agarrar doces e zombam da própria infantilidade: penduramse à vida como palha e ainda fazem troça por estarem pendurados. Sua sabedoria é a seguinte: 'Tolo é aquele que permanece vivo, mas somos todos nós também tolos! E isto é a maior tolice da vida!' [...;] eles querem se livrar da vida. $\bigcirc$ que lhes importa, se outros acabam se prendendo mais firmemente a ela com correntes e dádivas? E vós também, vós para quem a vida é trabalho árduo e inquietação, não estais por demais cansados da vida? Não estais por demais maduros para o sermão da morte? Vós todos que amais o trabalho árduo que é rápido, novo, estranho — vós suportais-vos mal a vós mesmos e ao vosso trabalho, o que é fuga e desejo deves esquecerdes de vós mesmos. Se acreditásseis mais na vida, não vos entregaríeis tanto ao momento corrente. Porém, não tendes em vós conteúdo suficiente para esperar - e menos ainda para a preguiça!" (NIETZSCHE, 2014, p. 62-64). Em mesmo sentido vão as críticas contundentes e avassaladoras que FORRESTER (2002) tece contra uma sociedade viciada em se determinar apenas em uma lógica de trabalho, desempenho e produção, sem espaço para a criatividade, a arte, a reflexão, a filosofia e o ócio. 


\section{Somente a rebeldia criativa, aliada à}

\section{retomada da politicidade e da busca por}

soluções de compromisso dedicadas

a recolocar as culturas de cada povo

e seus respectivos Estados nos eixos

da persecução dos seus próprios

objetivos (especialmente de seus

direitos fundamentais), no sentido de

uma irrestrita autodeterminação, poderá

reerguer a plena vitalidade e o orgulho do

Estado de direito ocidental

Talvez, aliás, os caminhos para uma superação dos atuais paradigmas tão fortemente antidemocráticos passem justamente por estabelecer soluções inovadoras, mas também complexas, portanto opostas ao império da incultura. "A ditadura da transparência aniquila o vago, o opaco, o complexo" (HAN, 20I7a, p. 205). O que as instigantes denúncias de Byung-Chul Han evidenciam indubitavelmente é a urgência desse exercício, de um repensar rebelde das tão aclamadas fórmulas padronizadas do neoliberalismo. Somente a rebeldia criativa, aliada à retomada da politicidade e da busca por soluções de compromisso dedicadas a recolocar as culturas de cada povo e seus respectivos Estados nos eixos da persecução dos seus próprios objetivos (especialmente de seus direitos fundamentais), no sentido de uma irrestrita autodeterminação, poderá reerguer a plena vitalidade e o orgulho do Estado de direito ocidental.

\section{CONSIDERAÇ̃̃ES FINAIS}

Dirá Mangabeira Unger: "As ideias por si sós não mudam o mundo. Sem ideias, porém, não podemos mudá-lo" (UNGER, 20I8, p. I3) ${ }^{47}$. A frase, de compreensibilidade particularmente interessante para um espírito hegeliano, cala fundo na alma daqueles que vivem sob o domínio feroz de um efetivo império. Como buscamos discutir neste artigo, sob império, a atitude usual dos homens ocidentais, desde o helenismo, tem sido um mergulho na subjetividade e numa suposta liberdade interior.

A essa liberdade de Epiteto, que, preso ao tronco e escravizado, se afirmava

47 E notavelmente segue imediatamente em seu raciocínio para dizer: "As que mais importam são aquelas que ligam o entendimento do existente à imaginação do possível — do possível adjacente, aquele que podemos alcançar a partir da situação em que nos encontramos, com os meios que já temos ou que podemos providenciar." (UNGER, 2018, p. 13) 
tão livre quanto César no trono, se contrapõe uma liberdade muito mais verdadeira e efetiva, a liberdade política, que adquire força palpável no processo de autodeterminação dos destinos de uma comunidade que se vê, por ora, interditada pelo domínio imperial que impõe sua vontade externamente e contra toda possibilidade de reflexão. A mudança na topologia da violência do império presente não modifica essencialmente as questões, os problemas e as eventuais tentativas de solução que se possa imaginar.

De fato, buscamos justamente instar o sentimento da urgência de se retomarem em mãos próprias os destinos do Estado de direito, e do nosso Estado brasileiro, em particular. Isto é, de se repolitizarem todas as instâncias que o domínio imperial sub-repticiamente vem despolitizando e desideologizando. De se reativar a negatividade que o fetiche da transparência irrestrita vem furtando ao humano. Para tal imensa e instigante tarefa, buscamos justamente retomar um termo do próprio império, que pejorativamente denuncia aqueles poucos Estados no mundo que ainda ousam se colocar contra o seu domínio absoluto: Estados rebeldes.

Ressignificada, a rebeldia estatal se coloca como abertura e desafio de criatividade para a reconfiguração dos diversos momentos do Espírito Objetivo que a sanha imperial pela ocultação da violência envolvida nos mecanismos de seu próprio domínio acabou por estilhaçar. Poesia, sabedoria, rebeldia, teimosia, utopia. Como na música que serviu de epígrafe a este texto, que a arte proveja a intuição necessária para este nosso imenso desafio.

* Professor da Faculdade de Direito da Universidade Federal de Uberlândia, doutor em Direito pela Universidade Federal de Minas Gerais (UFMG), mestre e bacharel em Direito pela Universidade de São Paulo (USP), mestre em Biologia pela USP, bacharel em Biologia pela UFMG. Membro do Grup Internacional de Recerca "Cultura, Història i Estat" (Girche), coordenado pelos professores doutores Gonçal Mayos Solsona (Universitat de Barcelona) e José Luiz Borges Horta (UFMG). Parte substancial deste trabalho foi desenvolvido quando o autor era bolsista financiado pelo CNPq. E-mail: hugorezende20@yahoo.com.br ** Graduando em Ciências do Estado pela UFMG, pesquisador voluntário de iniciação científica no projeto "Ciências do Estado: caminhos e soluções institucionais para o Brasil" e monitor bolsista da UFMG, sob orientação do prof. dr. José Luiz Borges Horta. Membro do Girche. E-mail: joaopedrobcarvalho@ gmail.com

Texto recebido em 29 de maio de 2021; aprovado em 8 de julho de 2021. 
AGAMBEN, Giorgio. Homo sacer: o poder soberano e a vida nua I. Tradução Henrique Burigo. Belo Horizonte: Editora UFMG, 2002.

ARISTÓTELES. Política. Tradução Antônio Campelo Amaral e Carlos de Carvalho Gomes. Lisboa: Vega, 1998.

BAUDRILLARD, Jean. A transparência do mal: ensaio sobre os fenômenos extremos. Tradução Estela dos Santos Abreu. Campinas: Papirus, 1992.

CARDOSO, Paulo Roberto. Diatética cultural: Estado, soberania e defesa cultural. 2016. 206f. Tese (Doutorado em Direito) — Faculdade de Direito, Universidade Federal de Minas Gerais, Belo Horizonte, 2016.

COSTA MATOS, Andityas Soares de Moura. O estoicismo imperial como momento da ideia de justiça. Rio de Janeiro: Lumen Juris, 2010.

ECO, Umberto. O nome da rosa. Tradução Aurora Fornoni Bernardini e Homero Freitas de Andrade. Rio de Janeiro: Record, 1995.

FORRESTER, Viviane. O horror econômico. Tradução Álvaro Lorencini. São Paulo: Editora Unesp, 2002.

FOUCAULT, Michel. História da loucura. Tradução José Teixeira Coelho Netto. São Paulo: Perspectiva, 1972.

História da sexualidade. Tradução Maria Thereza C. Albuquerque; J. A. Guilhon Albuquerque. Rio de Janeiro: Graal, 1988. 3 v.

Vigiar e punir: o nascimento da prisão. Tradução Raquel Ramalhete. Petrópolis: Vozes, 1999.

FUKUYAMA, Francis. O fim da história e o último homem. Tradução Aulyde Soares Rodrigues. Rio de Janeiro: Rocco, 1992.

HAN, Byung-Chul. Agonia do Eros. Tradução Enio Paulo Giachini. Petrópolis: Vozes, 2017c.

A salvação do belo. Tradução Gabriel SalviPhilipson. Petrópolis: Vozes, 2019a.

2019d.

Hegel y el poder: un ensayo sobre la amabilidad. Tradução Miguel Alberti. Barcelona: Herder,

Hiperculturalidade: cultura e globalização. Tradução Gabriel SalviPhilipson. Petrópolis: Vozes, $2019 b$.

No enxame: perspectivas do digital. Tradução Lucas Machado. Petrópolis: Vozes, 2018.

O que é poder?. Tradução Gabriel Salvi Philipson. Petrópolis: Vozes, 2019c.

Sociedade da transparência. Tradução Enio Paulo Giachini. Petrópolis: Vozes, $2017 b$.

Sociedade do cansaço. Tradução Enio Paulo Giachini. Petrópolis: Vozes, 2017d.

Topologia da violência. Tradução Enio Paulo Giachini. Petrópolis: Vozes, 2017a.

HEGEL, Georg Wilhelm Friedrich. Enciclopédia das ciências filosóficas em compêndio (1830): a filosofia do espírito. Tradução Paulo de Meneses. São Paulo: Loyola, 1995. v. 3.

Lecciones sobre filosofia de la religión: introducción y concepto de religión. Tradução Ricardo Ferrara. Madrid: Alianza, 1998. v. 1.

Linhas fundamentais da filosofia do direito: ou direito natural e ciência do Estado em compêndio. Tradução Paulo Meneseset al. São Leopoldo: Unisinos; Loyola, 2010.

Princípios da filosofia do direito: ou direito natural e ciência política em compêndio. Tradução Paulo Meneses et al. Porto Alegre: Fênix, 2021.

HENRIQUES, Hugo Rezende; CARVALHO, João Pedro Braga de. Conhece-te a ti mesmo: Hegel e o destino do Estado de direito. In: TASSINARI, Ricardo Pereira; BAVARESCO, Agemir; MAGALHÃES, Marcelo Marconato (Org.). Hegel e a contemporaneidade. Porto Alegre: Fundação Fênix, 2020, p. 347-358. 
HORTA, José Luiz Borges. Dialética do Poder Moderador: ensaio de uma ontoteleologiado Estado do Brasil. 2020. 257f. Tese (Cátedra em Teoria do Estado)_ Faculdade de Direito, Universidade Federal de Minas Gerais, Belo Horizonte, 2020.

Entre o Hegel racional e o Hegel real. In: BAVARESCO, Agemir; MORAES, Alfredo. (Org.).

Paixão e astúcia da razão. Porto Alegre: Editora Fi, 2013. p. 125-142.

Hegel, paixão e História. In: HORTA, José Luiz Borges; SALGADO, Karine. História, Estado e idealismo alemão. Belo Horizonte: Editora UFMG, 2017, p. 73-82.

La era de la justicia: derecho, Estado y limites a la emancipación humana, a partir del contexto brasileño. Astrolabio: Revista Internacional de Filosofía, v. 11, p. 75-85, 2011.

Ratio juris, ratiopotestatis: breve abordagem da missão e das perspectivas acadêmicas da filosofia do direito e do Estado. Revista da Faculdade de Direito. Belo Horizonte, v. 49, p. 145-160, 2006.

Urgência e emergência do constitucionalismo estratégico. Revista Brasileira de Estudos Constitucionais, v. 23, p. 783-806, 2012.

FREIRE, Thales Monteiro; SIQUEIRA, Vinícius de. A era pós-ideologias e suas ameaças à política e ao Estado de direito. Confluências, Niterói, v. 14, p. 120-133, 2012.

KINDLEBERGER, Charles Poor. Dominance and leadership in the international economy. International Studies Quarterly, p. 242-254, 1981.

The world in depression: 1929-1939. Berkeley: University of California Press, 1986.

KLEIN, Naomi. A doutrina do choque: a ascensãodo capitalismo de desastre. Tradução Vania Cury. Rio de Janeiro: Nova Fronteira, 2008.

MAYOS SOLSONA, Gonçal. Conflictos de legitimación en la turboglobalización. In: BILBENY, Norbert (Coord.). Legitimidad y acción política. Barcelona: Universitat de Barcelona, 2018, p. 317-338.

Genealogia i crítica del pensamentúnic. In: CASTANY MAGRANER, Bernat (Org.). Globalització: pensamentúnic. Barcelona: Liceu Joan Maragall; La Busca Edicions, 2000, p. 17-40.

Homo obsoletus: precariedade e desempoderamento na turboglobalização. Barcelona: Linkgua-Digital, 2019.

Nuevos "fenómenos-inter": interconstitucionalidad e interculturalidad. In: ; REMOTTI CARBONELL, José Carlos; MOYANO DÍAZ, Yanko (Ed.). Interrelación filosófico-jurídica multinivel: estudios desde la interconstitucionalidad, la interculturalidad y la interdisciplinariedad para un mundo global. Barcelona: Linkgua Ediciones, 2016, p. 39-61.

MIDDELAAR, Luuk van. Politicídio: o assassinato da política na filosofia francesa. Tradução Ramon Alex Gerrits. São Paulo: É Realizações, 2015.

MORUS, Thomas. Utopia. Tradução Anah de Melo Franco. Brasília: Editora UnB, 2004.

MOUFFE, Chantal. Sobre o político. Tradução Fernando Santos. São Paulo: WMF Martins Fontes, 2015.

NIETZSCHE, Friedrich Wilhelm. A genealogia da moral. Tradução Mário Ferreira dos Santos. Petrópolis: Vozes, 2013.

Assim falou Zaratustra: um livro para todos e para ninguém. Tradução Carlos Duarte e Anna Duarte. São Paulo: Martin Claret, 2014.

ORTEGA Y GASSET, José. A rebelião das massas. Tradução Felipe Denardi. Campinas: Vide, 2016.

PLATÃO. A República. Tradução Maria Helena da Rocha Pereira. 13. ed. Lisboa: Fundação Calouste Gulbenkian, 2012.

SALDANHA, Nelson. Ordem e hermenêutica. Rio de Janeiro: Renovar, 2003.

SALGADO, Joaquim Carlos. A ideia de justiça no mundo contemporâneo: fundamentação e aplicação do direito como maximum ético. Belo Horizonte: Del Rey, 2007. 
Estado ético e Estado poiético. Revista do Tribunal de Contas do Estado de Minas Gerais. Belo Horizonte, v. 27, n. 2, p. 37-68, abr.-jun. 1998.

SCHMITT, Carl. O conceito do político. Tradução Alexandre Franco de Sá. Lisboa: Edições 70, 2020.

O conceito do político e teoria do partisan. Tradução Geraldo de Carvalho. Belo Horizonte: Del Rey, 2008.

SÓFOCLES. Prometeu acorrentado. In: SÓFOCLES. Rei Édipo; Antígone; Prometeu acorrentado. Tradução J. B. Mello e Souza. Rio de Janeiro: Ediouro, 2000, p. 113-137.

SOUZA, Henrique José da Silva. Teoria da (in)decisão política: uma investigação da democracia sitiada pela sondocracia. 2015. 147f. Dissertação (Mestrado em Direito) — Faculdade de Direito, Universidade Federal de Minas Gerais, Belo Horizonte, 2015.

SPINOZA, Baruch. Ética. Tradução Tomaz Tadeu. Belo Horizonte: Autêntica, 2009.

UNGER, Roberto Mangabeira. Depois do colonialismo mental: repensar e reorganizar o Brasil. São Paulo: Autonomia Literária, 2018.

Necessidades falsas: introdução a uma teoria social antideterminista a serviço da democracia radical. Tradução Arnaldo Sampaio de Moraes Godoy. São Paulo: Boitempo, 2005.

O direito e o futuro da democracia. Tradução Caio Farah Rodriguez e Marcio Soares Grandchamp. São Paulo: Boitempo, 2004. 